\title{
Diatom diversity in headwaters influenced by permafrost thawing: First evidence from the Central Italian Alps
}

\author{
Federica Rotta, ${ }^{1 *}$ Leonardo Cerasino, ${ }^{2}$ Anna Occhipinti-Ambrogi, ${ }^{1}$ Michela Rogora, ${ }^{3}$ Roberto Seppi,${ }^{1}$ Monica Tolotti ${ }^{2}$ \\ ${ }^{1}$ Department of Earth and Environmental Sciences, University of Pavia, Via S. Epifanio 14, Pavia; ${ }^{2}$ Department of Sustainable \\ Agro-ecosystems and Bioresources, Research and Innovation Centre, Fondazione Edmund Mach, Via E. Mach 1, S. Michele all'Adige; \\ ${ }^{3}$ CNR Water Research Institute, Largo Tonolli 50, Verbania-Pallanza, Italy
}

\begin{abstract}
Glacier melting and permafrost thawing are the most evident effects of the current climate change that is strongly affecting high mountain areas, including the European Alps. As the thawing rate of subsurface ice is lower than for glacier ice, it is expected that, while glaciers retreat, an increasing number of Alpine headwaters will become more influenced by permafrost degradation during the $21^{\text {st }}$ century. Despite the expected change in the relative importance of glacier and permafrost in determining Alpine hydrology, studies addressing effects of permafrost thawing on chemical and, especially, biological features of adjacent surface waters are still scarce. The present study contributes to characterise the epilithic and epiphytic diatom diversity in a set of permafrost-fed headwaters in three subcatchments differing in bedrock lithology of the Italian Central Alps (Trentino Alto-Adige) in relation to water chemistry and habitat features. In addition, it explores chemical and biological differences between permafrost-fed streams and headwaters with no direct contact to permafrost, namely glacier-fed (kryal) and precipitation-/groundwater-fed (rhithral) streams. Permafrost-fed waters showed higher electrical conductivity and enhanced ion concentrations than glacier- and precipitation-fed waters, while concentration of trace elements (e.g. Sr, Ni, Zn, As) were more irregularly distributed among waters of different origin, though they showed a tendency to reach higher levels in permafrost-fed waters. Diatom species richness and diversity were lower in permafrost-fed headwaters, and were principally related to water $\mathrm{pH}$ and trace metal concentrations. Epiphytic diatom assemblages were more diverse than epilithic ones, independently from the water origin, while differences in species composition were not sufficient to unequivocally identify a typical diatom composition for the different water types considered in this study.
\end{abstract}

Key words: Diatoms; biodiversity; Alpine headwaters; mountain permafrost; rock-glacier; water chemistry.

Received: November 2018. Accepted: December 2018.

\section{INTRODUCTION}

Under the influence of the current global warming (IPCC, 2013), the European Alps have experienced an average temperature increase of about $2^{\circ} \mathrm{C}$ since the beginning of the $20^{\text {th }}$ century, which is twice as much as the global average (EEA, 2009). This trend is expected to continue with an average temperature increase of $1.5^{\circ} \mathrm{C}$ (in comparison with 1961-1990 period) by the first half of $21^{\text {st }}$ century, and up to $3.5^{\circ} \mathrm{C}$ during the second half (Gobiet et al., 2014).

The cryosphere reduction is the most evident effect of climate change in high mountain areas. Mountain glaciers are highly sensitive to the rising air temperature and their melting rate, estimated as $\sim 2 \mathrm{~km}^{3} \mathrm{y}^{-1}$ in the European Alps (Haeberli et al., 2017), has increased since the 1980s, causing the loss of $\sim 50 \%$ of their ice volume (Beniston et al., 2018). At this rate, $80-100 \%$ of the glaciers in the Alps are predicted to disappear by the end of the century (Zemp et al., 2006; Slemmons et al., 2013), leading to alterations in hydrological regimes, water chemistry and biodiversity in glacial-fed rivers (Milner et al., 2017).
Mountain permafrost (i.e. soil or rock that remains at or below $0^{\circ} \mathrm{C}$ for at least two consecutive years, Dobinski, 2011), is also an important component of the Alpine cryosphere that is threatened by climate change (Beniston et al., 2018), and its extent in the European Alps is estimated to exceed that of glaciers (about $6200 \mathrm{~km}^{2}$ if considering an index $\geq 0.5$, Boeckli et al., 2012). The most common permafrost evidence in the Alps are rock glaciers, i.e. landforms composed by a mixture of ice and debris and, if active, slowly creeping downslope (Schoeneich et al., 2011). Rock glaciers are considered as an important water reserve for mountain areas (Jones et al., 2018).

At present, glaciers and snowpack represent the main drivers of the Alpine hydrology, as their seasonal melting is tightly associated with surface and groundwater flow (Jansson et al., 2003), while permafrost thawing represents a secondary source to Alpine freshwater (Krainer et al., 2007; 2011). In fact, subsurface ice is considered as less climatically sensitive than glaciers (Jones et al., 2018) and its thawing rate is estimated to be 10-100 times slower than for glaciers due to the thermal 
buffering provided by the thick debris coating (Harris and Pedersen, 1998). Nevertheless, permafrost thawing and its relative importance for the Alpine hydrology is expected to increase during the $21^{\text {st }}$ century due to warmer and prolonged summers and reduced precipitation (Haeberli et al., 2017).

Despite the expected change in the relative importance of the major components of the Alpine cryosphere, the understanding of the possible cascading effects of permafrost degradation on water quality and ecology of Alpine freshwater is still largely incomplete. Insights into the effects of rock glacier thawing on inorganic chemistry of Alpine headwaters were provided by some recent case studies (Krainer et al., 2007; Thies et al., 2007, 2013, 2018; Colombo et al., 2018a; Engel et al., 2018). Compared to waters fed by glacier melt or atmospheric precipitation and groundwater, headwaters emerging from active rock glaciers are commonly characterised by higher electrical conductivity (EC) and concentration of major ions, in particular $\mathrm{Mg}^{2+}, \mathrm{Ca}^{2+}$ and $\mathrm{SO}_{4}{ }^{2-}$ (Colombo et al., 2018b). In addition, elevated trace metal concentrations (e.g. $\mathrm{Al}, \mathrm{Fe}, \mathrm{Ni}, \mathrm{Sr}$ ) are often detected in permafrost-fed headwaters, especially in metamorphic watersheds (Krainer et al., 2007; Thies et al., 2007, 2013; Ilyashuk et al., 2014; Engel et al., 2018).

In general, studies specifically addressing the impact of deglaciation on the biota of Alpine streams are scarce (Fell et al., 2017; Hotaling et al., 2017; Brown et al., 2018), and studies on the effects of permafrost thaw on the headwater biota are still occasional. Primary producers are particularly poorly investigated, despite benthic algae (especially diatoms) play a key ecological role in Alpine freshwaters (where external organic input is usually very scarce) as energy source for consumers (Rott et al., 2006). Nevertheless, first studies show that epilithic diatom assemblages of permafrost-fed running waters are mainly influenced by decrease in water $\mathrm{pH}$ and increase in EC and trace metals that appear to be able to induce significant changes in both species' composition and diversity (Thies et al., 2013; Lösch et al., 2015).

Scope of the present work is to contribute in filling the knowledge gap on diatom diversity in permafrost-fed headwaters of the Italian Central Alps (Trentino AltoAdige) in relation to water chemistry and habitat features. The study also aims at enlarging the perspective from one to several sub-catchments and at comparing species richness and diversity of epilithic and epiphytic diatom assemblages. Considering the predicted importance of permafrost in determining hydrology, chemistry and biology of headwater in a near future characterized by disappearing glaciers, this work aims also at exploring differences between permafrost-fed streams and headwaters with no direct contact with permafrost, namely glacier-fed (kryal) and precipitation- /groundwater-fed (rhithral) streams. This aspect may be ecologically relevant as waters emerging from active rock-glaciers are considered as potential refugia for the kryal biodiversity (Hotaling et al., 2017), and as possible stepping stones for the colonization of areas exposed by glacier retreat by organisms of lower altitudes.

\section{METHODS}

\section{Study sites}

A set of 16 headwaters of different origin were studied in three sub-catchments of the Italian Central Alps (Trentino Alto-Adige), i.e. Sulden/Solda (SU), La Mare (MR) and Amola (AM) valleys (Fig. 1 and Tab. 1).

The lithology of the studied areas consists almost exclusively of crystalline bedrocks. SU and MR valleys, which are located respectively in the northern and southern regions of the Ortles-Cevedale group and belong to the Austroalpine domain of the Central Alps, are dominated by Pre-permian metamorphic rocks, and show prevalence, respectively, of phyllades and granitic orthogneiss, and of micaschists (Montrasio et al., 2012). The bedrock of the sampled area in the AM Valley, which belongs to the Southalpine domain, consists of Oligocene intrusive tonalite rocks (Callegari and Brack, 2002).

The three sub-catchments include glacial landforms of different size and with different degree of debris cover that ranges from clean glaciers, i.e. La Mare and Suldner/ Solda glaciers (MR and SU valleys, respectively) to almost completely debris-covered glaciers, i.e. Amola (AM Valley) and Klein Angelus/Angelo Piccolo glaciers (SU Valley). Permafrost landforms are widespread in all the three areas, and mainly include active rock glaciers, and inactive and relict rock glaciers at lower elevations. Vegetation is absent or very sparse in the upper range of each studied area, while alpine meadows and sparse shrubs reach 2500-2600 $\mathrm{m}$ asl, according to the different orographic features of each sub-catchment.

The mean annual precipitation ranges from 800-950 $\mathrm{mm} \mathrm{y}^{-1}$ at the floor of the SU Valley (Adler, 2015) to $\sim 1200 \mathrm{~mm} \mathrm{y}^{-1}$ in the AM Valley (Baroni et al., 2004). Studies conducted in the past three decades indicate that these areas are affected by moderate atmospheric deposition of nitrogen $(\mathrm{N})$ compounds, originating from the emission sources located in the Po Plain, one of the most densely inhabited and industrialized regions of Europe (Rogora et al., 2006; Marchetto et al., 2014).

\section{Sampling and laboratory analysis}

Water and diatom samples were collected in late summer 2016 (between late August and early September), under condition of maximum melt water contribution from glaciers and rock glaciers and no snowmelt, in order 
to capture the highest diatom biodiversity (Rott et al., 2006; Uehlinger et al., 2010). Headwaters fed by permafrost and glaciers (RG and GL, respectively), were sampled at each studied sub-catchment, while rhithral waters fed by atmospheric precipitation, groundwater or of mixed origin (REF), and with no direct contact with permafrost and glaciers, could be found only in the MR and AM valleys (Fig. 1 and Tab. 1).
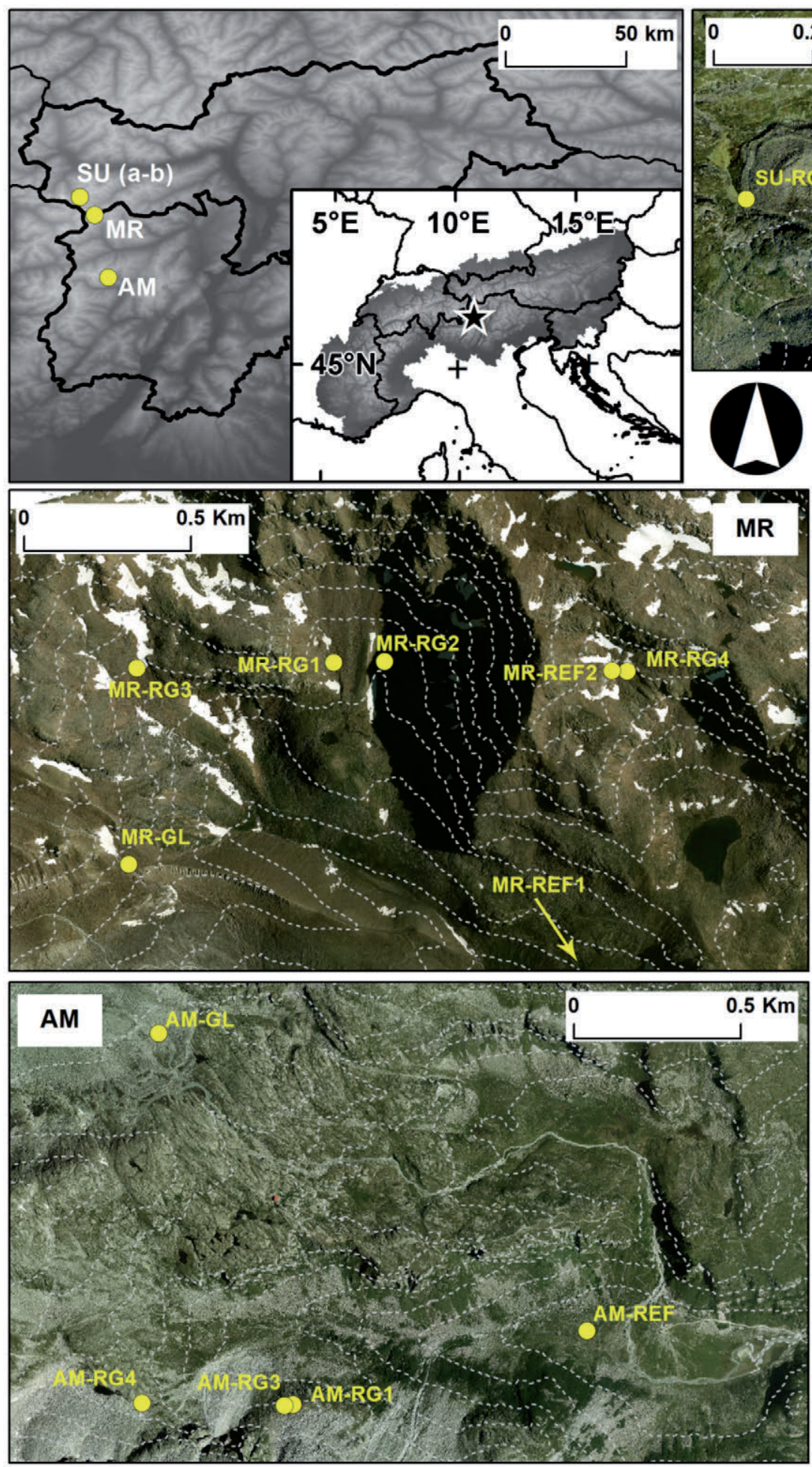

Fig. 1. Location of the three sub-catchments surveyed in the Italian Central Alps (uppermost left panel) and detailed maps (other panels) indicating the location of the sampled headwaters within each sub-catchment. Yellow bullets indicate the sampling sites at each surveyed headwater. The background orthophotos were downloaded from the websites of the Provincia Autonoma di Trento (https://webgis.provincia.tn.it) and the Provincia Autonoma di Bolzano (http://geocatalogo.retecivica.bz.it/geokatalog). SU (a) and SU (b), portions of the Sulden/Solda Valley located downstream of the glaciers Klein Angelus/Angelo Piccolo and Suldner/Solda, respectively; MR, La Mare Valley; AM, Amola Valley. 
In the SU Valley, streams fed by the Klein Angelus/Angelo Piccolo (SU-GL1) and Suldner/Solda (SU-GL2) glaciers were surveyed, together with two springs emerging from two active rock-glaciers located close to each of these two glaciers (SU-RG1 and SU-RG2, respectively, Fig. 1). As the first RG is part of the periglacial belt around the Klein Angelus/Angelo piccolo glacier, it is partially flushed by glacial melting water flowing underground (Brighenti, pers. comm). Seven different headwaters were surveyed in the MR Valley (Fig. 1). On the left side of the valley, active rock glaciers and talus slopes with probable presence of permafrost (Carturan et al., 2016) originate small streams that partially flow underground due to the slope morphology. Four springs emerging from the lowest margin of rockglaciers or talus slopes (Tab. 1) were sampled at altitudes between 2710 and $2890 \mathrm{~m}$ asl, while a glacial stream (MR-GL) emerging from La Mare glacier was sampled at $2898 \mathrm{~m}$ altitude on the right valley side (Fig. 1). Rhithral waters with no direct contact with permafrost were sampled in the upper part of the valley at $2890 \mathrm{~m}$ asl, and at the sub-catchment closing section at $2266 \mathrm{~m}$ asl (Tab. 1), upstream the confluence with the glacial stream. Discontinuous permafrost and active rock glaciers characterize the orographic right side of the AM Valley (Baroni et al., 2004; Seppi et al., 2012), were samples were collected from two springs emerging from an active rock glacier (AM-RG1 and AM-RG3 around $2300 \mathrm{~m}$ asl, Fig. 1) and from a talus slope (AM-RG4 at $2570 \mathrm{~m}$ asl) characterized by a very low permafrost index according to Boeckli et al. (2012). The glacial stream fed by meltwater of the Amola glacier (AM-GL), located on the left of the valley, was sampled at $2427 \mathrm{~m}$ altitude, while the rhithral stream collecting all non-glacial waters originating from the right side of the valley (AM-REF, Fig. 1) was sampled at $2027 \mathrm{~m}$ asl before the confluence with the glacial stream.

Each sampled headwater has been described by location (altitude and geographic coordinates) and qualitative variables, such as water discharge and turbidity and presence of vegetation inside and outside the water channel, which were empirically estimated on site (Tab. 1). Water temperature, electrical conductivity (EC), and turbidity (the latter only for the SU and part of MR valley) were measured in the field on site with portable conductivity and turbidity meters (WTW GmBH, Weilheim, Germany). Water turbidity of the other surveyed waters and water discharge were empirically estimated by observation during the sampling; water turbidity was given a value between 0 and 5 (Tab. 1).

Water samples for chemical analyses were collected in acid washed high density polyethylene (HDPE) bottles and

Tab. 1. Location, dominant geology, habitat characteristics of the 16 headwaters surveyed in the present study, and type of diatom samples collected.

\begin{tabular}{|c|c|c|c|c|c|c|c|c|c|c|c|}
\hline $\mathrm{Nr}$ & ID & Catc & Lat-X, Long-Y & $\begin{array}{c}\text { Altid } \\
\text { m a.s.l. }\end{array}$ & Geol & $\begin{array}{c}\text { Veg } \\
\text { In, Out }\end{array}$ & $\begin{array}{c}\text { Turb } \\
\text { NTU, (Est) }\end{array}$ & $\begin{array}{c}\text { Temp } \\
{ }^{\circ} \mathrm{C}\end{array}$ & $\begin{array}{l}\text { POM } \\
\% \text { DW }\end{array}$ & $\begin{array}{c}\mathrm{CO}_{3}{ }^{2-} \\
\% \mathrm{LOI}\end{array}$ & Dia \\
\hline 1 & SU-GL1 & A & 625341,5156147 & 2890 & $\mathrm{M}, \mathrm{ph}$, go &,-- & $42(2)$ & 3.0 & 10.9 & 0.10 & E \\
\hline 2 & SU-RG1 & A & 624406,5156079 & 2728 & $\mathrm{M}, \mathrm{ph}$, go &,++ & $6(1)$ & 1.1 & 46.5 & 0.9 & $\mathrm{E}, \mathrm{M}$ \\
\hline 3 & SU-GL2 & A & 622653,5148781 & 2726 & $\mathrm{M}, \mathrm{ph}$, go &,-- & $306(3)$ & 0.1 & 7.8 & 6.6 & E \\
\hline 4 & SU-RG2 & A & 622736,5149503 & 2579 & M, ph, go &,+- & $3(0)$ & 1.0 & 27.3 & 1.9 & $\mathrm{E}, \mathrm{M}$ \\
\hline 5 & MR-GL & $\mathrm{N}$ & 632904,5118237 & 2898 & $\mathrm{M}, \mathrm{ms}$ &,-- & n.a. (4) & 6.0 & 6.7 & 2.9 & E \\
\hline 6 & MR-RG1 & $\mathrm{N}$ & 627492,5144697 & 2710 & $\mathrm{M}, \mathrm{ms}$ &,-- & n.a. (0) & 2.4 & 25.4 & 3.9 & $\mathrm{E}$ \\
\hline 7 & MR-RG2 & $\mathrm{N}$ & 627645,5144701 & 2717 & $\mathrm{M}, \mathrm{ms}$ &,+- & n.a. (0) & 4.4 & 26.4 & 1.6 & $\mathrm{E}, \mathrm{M}$ \\
\hline 8 & MR-RG3 & $\mathrm{N}$ & 626902,5144681 & 2809 & $\mathrm{M}, \mathrm{ms}$ &,-- & n.a. (0) & 0.6 & 21.6 & 5.36 & E \\
\hline 9 & MR-RG4 & $\mathrm{N}$ & 628372,5144671 & 2890 & $\mathrm{M}, \mathrm{ms}$ &,+- & n.a. (0) & 2.1 & 27.3 & 1.35 & $\mathrm{E}, \mathrm{M}$ \\
\hline 10 & MR-REF1 & $\mathrm{N}$ & 628325,5144673 & 2266 & $\mathrm{M}, \mathrm{ms}$ &,++ & n.a. (0) & 10.6 & 52.5 & 12.4 & $\mathrm{E}, \mathrm{M}$ \\
\hline 11 & MR-REF2 & $\mathrm{N}$ & 628325,5144673 & 2898 & $\mathrm{M}, \mathrm{ms}$ &,+- & n.a. (0) & 9.4 & 78.1 & 1.7 & $\mathrm{E}, \mathrm{M}$ \\
\hline 12 & AM-GL & $\mathrm{S}$ & 631622,5119213 & 2427 & I, to &,-- & n.a. (5) & 2.3 & 12.0 & 1.6 & E \\
\hline 13 & AM-RG1 & $\mathrm{S}$ & 632024,5118102 & 2321 & I, to & ++ & n.a (0). & 0.8 & 94.1 & 7.7 & $\mathrm{E}, \mathrm{M}$ \\
\hline 14 & AM-RG3 & $\mathrm{S}$ & 632024,5118102 & 2578 & I, to &,-- & n.a. (0) & 1.1 & 5.6 & 0.6 & $\mathrm{E}$ \\
\hline 15 & AM-RG4 & $\mathrm{S}$ & 631571,5118106 & 2385 & I, to &,+- & n.a. (0) & 4.5 & 41.5 & 4.8 & $\mathrm{E}, \mathrm{M}$ \\
\hline 16 & AM-REF & $\mathrm{S}$ & 632904,5118323 & 2027 & I, to &,++ & n.a. (0) & 8.1 & 21.7 & 13.9 & $\mathrm{E}, \mathrm{M}$ \\
\hline
\end{tabular}

ID, headwater code; AM, Amola Valley; MR, La Mare Valley; SU, Sulden/Solda Valley; GL, glacier-fed; RG, permafrost-fed; REF, rhithral streams fed by precipitation and/or groundwater; Catc, major river catchment to which each sampled headwater belongs; S, Sarca River; N, Noce River; A, Adige River; Lat-X and Long-Y, UTM latitude and longitude; respectively; Altid, altitude, Geol, geology of the watershed; I, intrusive; M, metamorphic; to, tonalite; ms, micaschists; ph, phyllades; go, granitic orthogneiss; Veg, vegetation present in (In) or ouside (Out) each headwater; Turb, water turbidity measured as nephelometric turbidity units (NTU) and estimated ( 0 to 5 ) by direct observation (Est); n.a., not available; Temp, water temperature; POM, particulate organic matter of the epilithic biofilm; DW, dry weight; LOI, lost on ignition; Dia, diatom samples collected from each studied headwater; E, epilithic; M, epiphytic from submerged moss. 
preserved at dark and cool $\left(4^{\circ} \mathrm{C}\right)$ until analysis. Electrical conductivity (EC) at $20^{\circ} \mathrm{C}, \mathrm{pH}$, alkalinity, major ions $\left(\mathrm{Ca}^{2+}\right.$, $\left.\mathrm{Mg}^{2+}, \mathrm{Na}^{+}, \mathrm{K}^{+}, \mathrm{SO}_{4}{ }^{2-}, \mathrm{Cl}^{-}\right)$, and nutrients $\left(\mathrm{NO}_{3}-\mathrm{N}, \mathrm{NH}_{4}-\mathrm{N}\right.$, total nitrogen $(\mathrm{TN})$, soluble $\left(\mathrm{P}_{-}-\mathrm{PO}_{4}\right)$ and total phosphorous (TP), $\mathrm{SiO}_{2}$ ) were determined according to standard methods (APHA-AWWA-WPCF, 2017) at the FEM Hydrochemistry Lab. Water samples for the analyses of trace metals were filtered in the field through $0.2 \mu \mathrm{m}$ mesh polycarbonate filters, collected in acidified $100 \mathrm{~mL}$ HDPE bottles and immediately preserved adding $100 \mu \mathrm{L}$ of $\mathrm{HNO}_{3}$ $65 \%$ (APAT, CNR-IRSA, 2003). Trace metal concentrations were determined by inductively coupled plasma optical emission spectrometry (ICP-OES) with ultrasonic nebulizer at the water chemistry laboratory of the Water Research Institute of Verbania, Italy (CNRIRSA), formerly Institute of Ecosystem Study (CNR-ISE). Further details on the analytical methods and the quality assurance/quality controls adopted in the laboratory can be found at http://www.idrolab.ise.cnr.it/en/.

Samples for the analysis of the epilithic diatoms assemblages were collected by brushing the surface of 10 different stones randomly collected along a $\sim 10 \mathrm{~m}$ long section of each surveyed headwater, according to European Committee for Standardization (2014). An aliquot of each epilithic sample was immediately subsampled for the determination of organic and carbonate content according to Hauer and Lamberti (2011). Around $0.5 \mathrm{~g}$ of freeze-dried material was heated in a furnace at $550^{\circ} \mathrm{C}$ for 12 hours to quantify the percent content of particulate organic matter (POM), weighted and heated again at $950^{\circ} \mathrm{C}$ for 3 hours to determine the $\mathrm{CO}_{3}{ }^{2-}$ content to be used as an estimate of primary production. Epiphytic diatoms were yielded, wherever possible, by collecting and washing submerged mosses located in the water flow. Epiphytic diatoms were retrieved from the majority of the permafrost-fed and rhithral waters, while water mosses were absent in all the surveyed glacier-fed streams. All diatom samples were preserved in $70 \%$ ethanol till the cleaning in hot $30 \%$ $\mathrm{H}_{2} \mathrm{O}_{2}$, and $\mathrm{HCl} 37 \%$, and the permanent mounting in Naphrax ${ }^{\circledR}$ resin, refractive index of 1.7 (European Committee for Standardization, 2014). Oxidation of samples containing particularly resistant organic matter was obtained by adding $\mathrm{K}_{2} \mathrm{Cr}_{2} \mathrm{O}_{7}$ grain by grain (Tolotti, 2001). According to the European Committee for Standardization (2004), at least 400 valves were identified and enumerated along transects of each permanent slide under a Leica DM2500 microscope equipped with differential interference contrast optics and a 100x oilimmersion objective (1000x magnification). On the contrary, the total area of the slides relative to the glacialfed streams was scanned, due to the very low diatoms density. Taxon identification was based on standard literature (Krammer and Lange-Bertalot, 1986-2004;
Krammer, 2000; Lange-Bertalot, 2001; Lange-Bertalot et al., 2011, 2017), integrated by literature on recently revised taxa (Potapova and Hamilton et al., 2007; Hlúbikova et al., 2009).

\section{Data analysis}

Variability of $\mathrm{pH}$, major ions responsible for $\mathrm{EC}$ (i.e. $\mathrm{Ca}^{2+}, \mathrm{Mg}^{2+}$ and $\left.\mathrm{SO}_{4}{ }^{2-}\right)$, and more abundant nutrients $\left(\mathrm{NO}_{3}{ }^{-}\right.$ $\mathrm{N}, \mathrm{TP}$ and $\mathrm{SiO}_{2}$ ) in the surveyed waters of different origin was compared with one-way ANOVA tests or ANOVA tests on ranks, after testing the normal distribution of the data through a Kolmogorov-Smirnov distance test. Pairwise multiple comparison was performed following the Holm-Sidak method (Holm, 1979).

Diatom $\alpha$-diversity of epilithic and epiphytic assemblages was evaluated based on the Shannon Index (Shannon and Weaver, 1949) calculated on number of identified individuals for each taxon. The Evenness (Pielou, 1975) and Hill's index (Hill, 1973) were computed to obtain information on the heterogeneity of the assemblages. Other diatom data analyses were based on relative abundance (RA) of the diatom taxa identified. Preferences of the identified taxa for $\mathrm{pH}$, total phosphorous concentrations, and moisture were evaluated according to the classification proposed by Van Dam et al. (1994) for European freshwaters.

Non-metric multidimensional scaling (NMDS; Kruskal and Wish, 1978) was performed by R 3.2.2 (R Core Team, 2015) software in order to graphically evaluate differences between diatom assemblages identified on different substrata in the studied sites. NMDS was applied to a Bray and Curtis dissimilarity matrix (Legendre and Legendre, 1998) based on nontransformed relative abundances of the 42 diatom taxa reaching $\mathrm{RA} \geq 0.5 \%$ at least in two samples. These restrictions provided the analysis to be performed on an average $95 \%$ (84.7-99.7\%) of the total diatom abundance of the different samples. Epilithic and epiphytic diatom assemblages were evaluated simultaneously in order to obtain a direct comparison of the two diatom communities. Samples from the four glacier-fed streams were excluded from the analyses because of the very low number of valves identified in these samples (see below). Stress values of NMDS configurations with increasing numbers of dimensions were compared in order to evaluate the stability of the analysis and to identify the minimum number of dimensions that is sufficient to explain samples variability (Legendre and Legendre, 1998). A vector fitting analysis was applied to the sample scores on the final NMDS configuration, and computed using the $\mathrm{R}$ function envfit included in the vegan package ver. 2.3-0 (Oksanen et al., 2015) in order to identify the maximum correlation between the sample distribution within the NMDS ordination space and habitat features 
and water physical and chemical characteristics of the headwaters studied. Except for water temperature and $\mathrm{pH}$, all environmental and chemical data were log transformed $(y=\log (x+1))$ in order to reduce the variability within the data set. In addition, the relation between sample scores on the NMDS dimensions and the abundance of single diatom taxa and cumulative RA of diatoms with different preferences for $\mathrm{pH}, \mathrm{TP}$, and moisture was explored by correlation analysis. A negative Kolmogorov-Smirnov distance test indicated the Spearman rank correlation coefficient $(\rho)$ as suitable for exploring the correlation within the data matrix.

\section{RESULTS}

\section{Water chemistry}

All permafrost-fed waters were characterised at the sampling moment by low discharge (estimated as ranging from $\sim 1 \mathrm{~L} \mathrm{sec}^{-1}$ for the majority of RG springs to $\sim 5 \mathrm{~L}$ $\mathrm{sec}^{-1}$ for AM-RG4 and SU-RG1), low temperature (ranging from $0.6^{\circ} \mathrm{C}$ for springs to $4.4^{\circ} \mathrm{C}$ for waters emerging from talus slopes, i.e. MR-RG2 and AM-RG4), and very low water turbidity (Tab. 1). No significant differences emerged between the three studied subcatchments. On the other hand, the glacier-fed streams showed higher discharge (estimated as between 5 and 20 $\mathrm{L} \mathrm{sec}^{-1}$ ), high mineral turbidity and variable water temperature in relation to the distance of the sampling site from the glacier snout (Tab. 1).

The $\mathrm{pH}$ values of the majority of the surveyed waters ranged from acidic to neutral, while both the headwaters sampled downstream the Suldner/Solda Glacier (i.e. SUGL2 and SU-RG2) showed basic values (Supplementary Tab. 2). Although the one-way ANOVA test did not show significant differences in the median $\mathrm{pH}$ values of the three water types, glacier-fed and rhithral waters showed higher variability compared to permafrost-fed waters, whose $50 \%$ of $\mathrm{pH}$ values ranged between 6.6 and 6.9 (Fig. 2). Median alkalinity of the permafrost-fed waters $\left(5.9 \pm 20.3 \mu \mathrm{eq} \mathrm{L} \mathrm{L}^{-1}\right)$ was slightly, but not significantly, higher and more variable than values in glacier-fed and rhithral waters (Supplementary Tab. 2).

In general, permafrost-fed waters showed high EC values and ion concentrations (median $\mathrm{EC}=155 \pm 213 \mu \mathrm{S}$ $\mathrm{cm}^{-1}$ ), especially in MR and SU valleys (up to $516 \mu \mathrm{S}$ $\mathrm{cm}^{-1} \mathrm{EC}$ in MR-RG4), while all headwaters surveyed in the AM Valley showed scarce mineralization, with EC values never exceeding $20 \mu \mathrm{S} \mathrm{cm}^{-1}$ (Supplementary Tab. 2). The ions $\mathrm{Ca}^{2+}, \mathrm{Mg}^{2+}$ and $\mathrm{SO}_{4}{ }^{2-}$ were the most important contributors to the enhanced $\mathrm{EC}$ values recorded in the permafrost-fed waters, where they showed quite variable concentrations (Fig. 2). Due to this high variability, the ANOVA test on ranks (for non- normally distributed data) indicated that the median concentrations of these ions in permafrost-fed waters (i.e. $71.0,7.1$ and $21 \mathrm{mg} \mathrm{L}^{-1}$, respectively) were not significantly higher than in glacier-fed (i.e. 3.7, 0.5 and $6.8 \mathrm{mg} \mathrm{L}^{-1}$, respectively) and rhithral streams (i.e. 11.9, 2.9 and $38.8 \mathrm{mg} \mathrm{L}^{-1}$, respectively, Fig. 2, Supplementary Tab. 2). In addition, the difference may have been overlooked, since the power of the performed test $(0.105)$ was below the desired values of 0.800 , which implies a lower potential to detect differences where they actually exist. Concentrations of other ions $\left(\mathrm{Na}^{+}, \mathrm{K}^{+}, \mathrm{Cl}^{-}\right)$were quite low and did not show significant differences in the surveyed water types (Supplementary Tab. 2).

Concentrations of the trace metals were highly variable, as shown in Fig. 3, but only in a few cases they exceeded the European limits for drinking waters (EU 83/1998, Supplementary Tab. 2). Sr, Al, Zn and Fe showed the highest median values (Fig. 3), which reached $\sim 30 \mu \mathrm{g} \mathrm{L}^{-1}$ for $\mathrm{Sr}$ and $\mathrm{Al}$, and a pronounced variability, while other metals, such as $\mathrm{Ni}, \mathrm{Mn}$ and $\mathrm{Ba}$, showed median values $<3$ $\mu \mathrm{g} \mathrm{L}^{-1}$ but particularly high concentrations in some water samples (Supplementary Tab. 2). Concentrations of the majority of trace metals were very low in all the waters sampled in the AM sub-catchment, while the waters sampled in the MR sub-catchment showed higher concentrations (Supplementary Tab. 2). Permafrost-fed waters were enriched in some metals, particularly $\mathrm{Sr}, \mathrm{Zn}$ and $\mathrm{Ni}$, which reached the highest concentration in waters of the MR (e.g. up to $315 \mu \mathrm{g} \mathrm{L}^{-1} \mathrm{Sr}$ in MR-RG2 and $60 \mu \mathrm{g}$ $\mathrm{L}^{-1} \mathrm{Ni}$ in MR-RG3 and) SU sub-catchments (e.g. $410 \mu \mathrm{g}$ $\mathrm{L}^{-1} \mathrm{Sr}, 31 \mu \mathrm{g} \mathrm{L} \mathrm{L}^{-1} \mathrm{As}$, and $15 \mu \mathrm{g} \mathrm{L}^{-1} \mathrm{Ba}$ in SU-RG2). On the contrary, $\mathrm{Al}, \mathrm{Mn}$ and $\mathrm{Fe}$ showed higher concentrations in glacier-fed than in permafrost-fed waters in each subcatchment, and reached their maximum in the glacial stream of AM (i.e. $211 \mu \mathrm{g} \mathrm{L}^{-1} \mathrm{Al}$ and $250 \mu \mathrm{g} \mathrm{L} \mathrm{L}^{-1} \mathrm{Fe}$ in AM$\mathrm{GL}$ ), and MR catchments (i.e. $255 \mu \mathrm{g} \mathrm{L}-1 \mathrm{Al}$ and $80 \mu \mathrm{g} \mathrm{L}^{-1}$ $\mathrm{Mn}$ in MR-GL). The latter stream showed also the highest Zn concentration (i.e. $560 \mu \mathrm{g} \mathrm{L}^{-1}$, Supplementary Tab. 2).

All surveyed waters were very poor in soluble phosphorus (median $=2 \pm 1 \quad \mu \mathrm{g} \quad \mathrm{L}^{-1}$ ) and ammonia concentrations (median $=5 \pm 6 \mu \mathrm{g} \mathrm{L}^{-1}$, up to $27 \mu \mathrm{g} \mathrm{L}^{-1}$ in the glacier-fed site MR-GL, Supplementary Tab. 2). All glacier-fed streams were characterised by outstanding concentrations of total phosphorous $\left(\geq 70 \mu \mathrm{g} \mathrm{L}^{-1}\right)$, while concentrations of total nitrogen showed a strong decreasing gradient from the southernmost (4.8 $\mathrm{mg} \mathrm{L}^{-1}$ in AM-GL) to the northernmost glaciers (only $0.08 \mathrm{mg} \mathrm{L}^{-1}$ in SU-GL1, Supplementary Tab. 2). Median concentrations of $\mathrm{NO}_{3}-\mathrm{N}$ and $\mathrm{SiO}_{2}$ were significantly lower in glacier-fed waters of all sub-catchments than in permafrost-fed and rhithral waters (One-way Anova test, $\mathrm{P}<0.01$ ), while values in the permafrost-fed waters did not significantly differ from those of rhithral waters (Fig. 3). The highest $\mathrm{NO}_{3}-\mathrm{N}$ and $\mathrm{SiO}_{2}$ concentrations were detected in $\mathrm{RG}$ springs in the MR 
sub-catchment (i.e. $1.4 \mathrm{mg} \mathrm{L}^{-1}$ and $7.8 \mathrm{mg} \mathrm{L}^{-1}$ in MR-RG3 and MR-RG4, respectively, Supplementary Tab. 2).

The median content of POM of the epilithic diatom samples collected from the surveyed waters was $25.9 \pm 25.5 \%$ of the dry mass (Tab. 1), with glacier-fed samples showing the lowest median content $(9.3 \pm 2.5 \%)$.
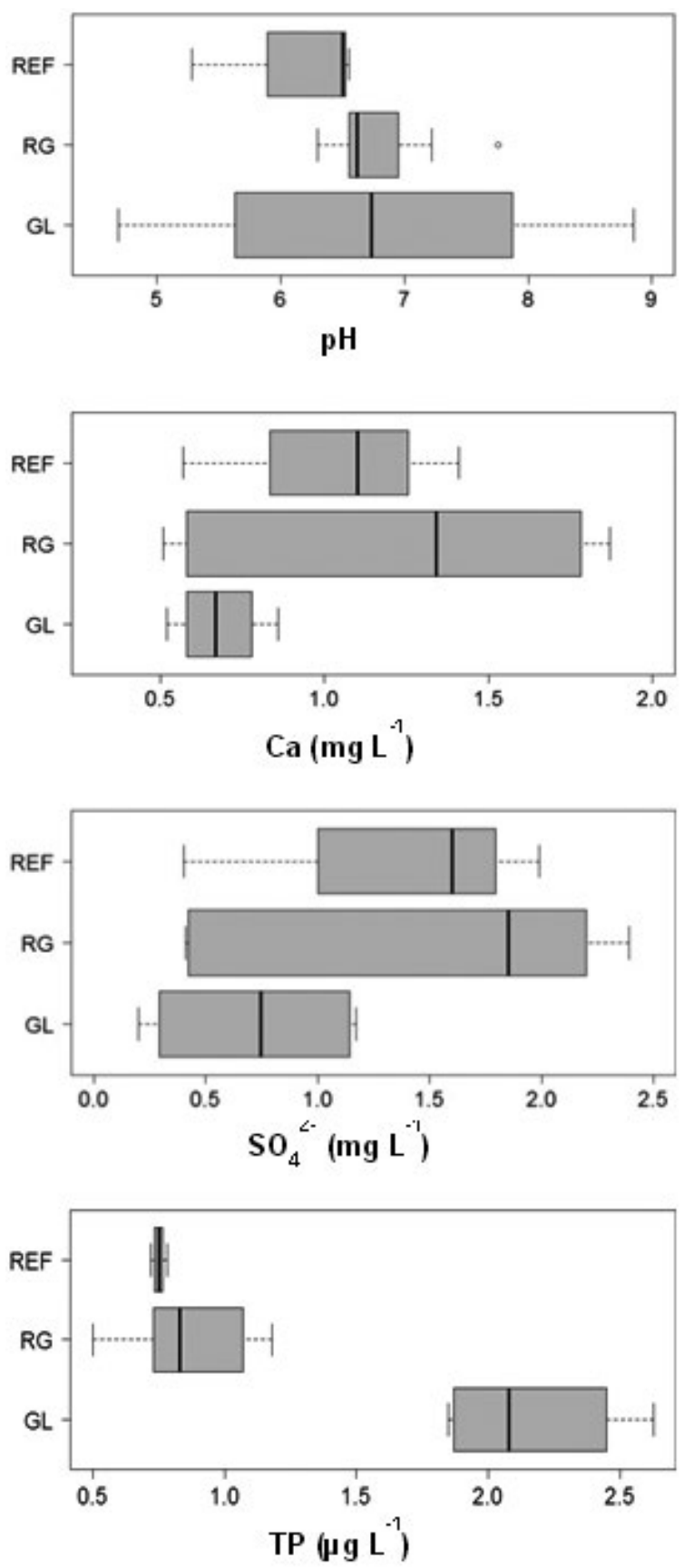

Permafrost-fed and rhithral waters showed a pronounced variability, with no evident relation to the presence of vegetation in the water bed or banks. Carbonate content was in general low (median $=2.4 \pm 4.1$ of the mineral ashes, Tab. 1), with lower values $(\leq 2.93 \%)$ in the samples from all the glacier-fed and several permafrost-fed waters, and
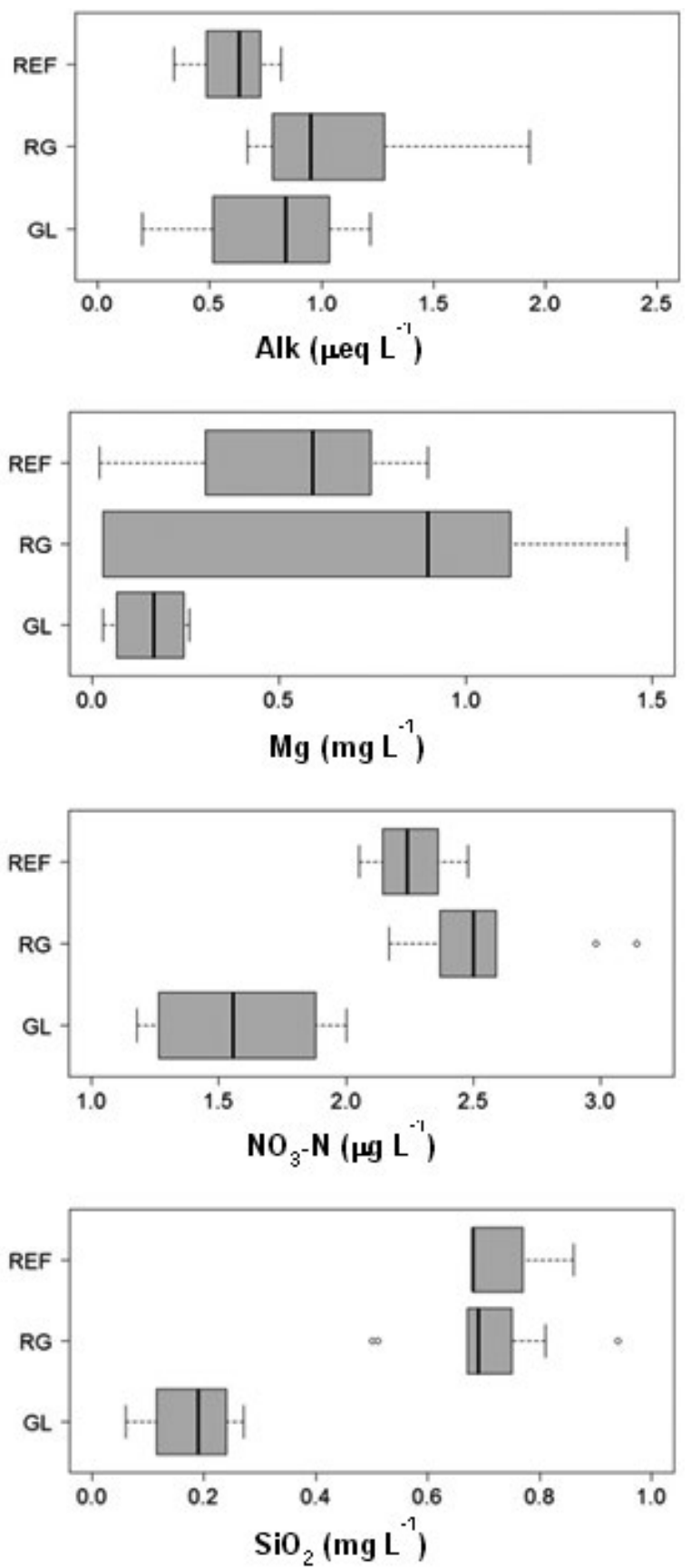

Fig. 2. Concentration ranges of selected water chemical variables measured in headwaters of different origin in the sub-catchments surveyed in the Italian Central Alps. All variables $\log$-transformed $(y=(\log x+1))$, except $\mathrm{pH}$. Complete data are available in Supplementary Tab. 1. GL, glacier-fed; RG, permafrost-fed; REF, rhithral waters fed by precipitation and/or groundwater with no direct contact with glaciers or permafrost. 
values exceeding $10 \%$ of the ash content only in the rhithral streams in the AM and MR sub-catchments (Tab. 1).

\section{Diatom diversity and ecological classification}

The taxonomical analysis of the 16 epilithic and 10 epiphytic samples collected in summer 2016 yielded a total of 120 diatom taxa. Epilithic diatom assemblages of all surveyed glacier-fed waters were extremely sparse, as only up to 42 valvae belonging to a few taxa (2-8) could be identified despite scanning the whole area of the slides (Supplementary Tab. 3.) Permafrost-fed and rhithral headwaters were characterized by denser diatom assemblages, which included several widespread taxa. The most common diatoms (i.e. reaching $\mathrm{RA} \geq 0.5 \%$ in more than 10 samples) were Achnanthidium minutissimum var. minutissimum (Kützing) Czarnecki, Diadesmis perpusilla (Grunow) Mann, Diatoma mesodon (Ehrenberg) Kützing, Psammothidium helveticum (Hustedt) Bukhtiyarova Round and $P$. daonense (Lange-Bertalot) Lange-Bertalot, and $P$. marginulatum (Grunow) Bukhtiyarova and Round (Tab. 2). The most abundant taxon was the rheophilous $A$. minutissimum var. minutissimum, (maximum $\mathrm{RA}=78 \%$ in the rhithral stream A-REF-M, Tab. 2) which accounted to $>30 \%$ of the total diatom abundance in the majority of the samples. Rare taxa, which reached $\mathrm{RA} \geq 0.5 \%$ in only one sample, are listed in Supplementary Tab. 4.

The epilithic diatom assemblages of the permafrost-

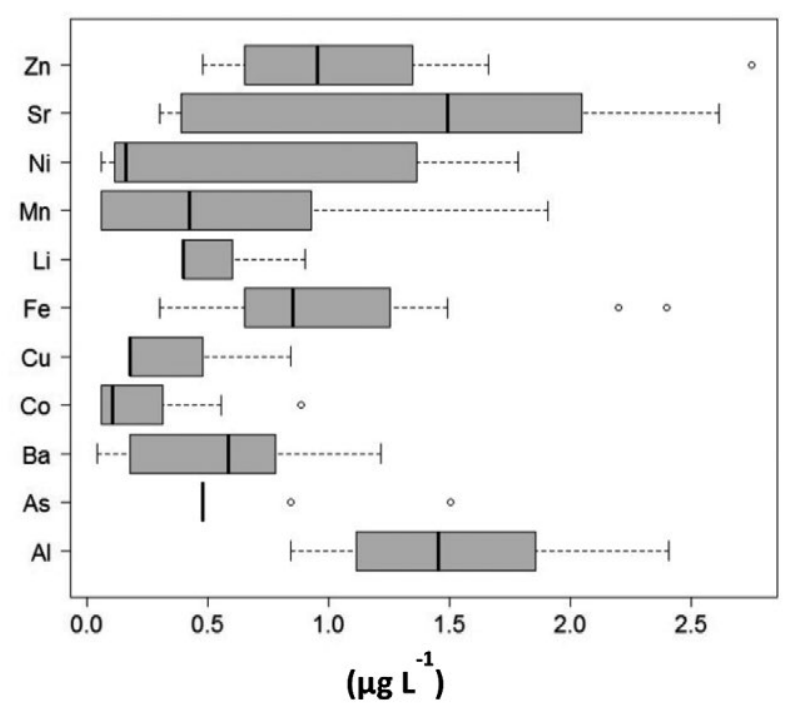

Fig. 3. Log-transformed $(y=(\log x+1))$ concentration ranges of the trace metals detected in headwaters of different origin in the sub-catchments surveyed in the Italian Central Alps. Complete data are in Supplementary Tab. 2. GL, glacier-fed; RG, permafrost-fed; REF, rhithral waters fed by precipitation and/or groundwater with no direct contact with glaciers or permafrost. fed waters sampled in the MR sub-catchment showed lower number of taxa, and lower $\alpha$-diversity (Shannon Index $<2$ ) and heterogeneity compared to permafrost-fed streams in the other sub-catchments (Shannon Index $>2$, Tab. 3). The sample collected from AM-RG4 showed the highest number of taxa (33), and the highest diversity and heterogeneity (Tab. 3). The epilithic diatom assemblages of the major reference streams of AM and MR subcatchments were comparably diverse, while number of taxa and diversity were much lower in both the samples from MR-REF2 (Tab. 3), due to a very pronounced dominance of $P$. helveticum ( $\mathrm{RA}=76 \%$, Tab. 2). On average, the epiphytic diatom samples showed higher species richness $(\mathrm{n}=23)$ and diatom diversity (S.I. $=2.5 \pm 0.1$, Tab. 3 ) in comparison to the epilithic ones $(\mathrm{n}=16$, S.I. $=1.9 \pm 0.1$, Tab. 3$)$, with highest number of taxa and Shannon Index in the AM-RG4 sample and, secondarily, in the springs emerging from rock-glaciers in the SU Valley (Tab. 3).

According to the ecological classification of Van Dam et al. (1994), the majority (i.e. $25 \%$ ) of the diatom taxa identified prefers circumneutral waters and this category accounted in average to $\sim 69 \%$ of the total diatom abundance in all the samples (Fig. 4a). In some samples with neutral $\mathrm{pH}$ values (e.g. MR-RG4 and SU-RG2) circumneutral taxa, such as A. minutissimum sensu lato, $D$. perpusilla and D. mesodon, were accompanied by higher proportions of alkaliphilus diatoms, such as Planothidium lanceolatum (Brébisson ex Kützing) LangeBertalot), Amphora pediculus (Kützing) Grunow (Fig. 4a), and A. lineare (W. Smith). Acidophilus taxa (i.e. P. marginulatum) represented the most abundant diatom category only in MR-RG3-E, while RA of the acidobiontic taxa Eunotia exigua (Brébisson ex Kützing) Rebenhorst exceeded $30 \%$ only in the epiphytic sample from MR-REF2 (Fig. 4a), in agreement with its quite acidic water pH (Supplementary Tab. 2). Diatom species found in all glacier-fed waters were mainly circumneutral or alkaliphilous, but this classification has to be considered as only indicative due to the very low number of diatom valvae identified in these samples.

Despite diatom taxa classified as indifferent to the water trophic status represent only $\sim 11 \%$ of all identified taxa, in average they accounted to around $40 \%$ of the total diatom abundances in all the samples studied (Fig. 4b). According to the very low $\mathrm{PO}_{4}-\mathrm{P}$ concentrations of all the surveyed headwaters, oligotraphentic taxa accounted to an average RA of around $22 \%$. However, some mesotraphentic (e.g. D. mesodon) and even eutraphentic taxa (e.g. P. lanceolatum and A. pediculus) reached high relative abundance in some of the analysed epiphytic samples, such as AM-RG1-M, AM-RG3-M, and MRRG4-M (Fig. 4b).

Only around $10 \%$ of all identified diatom taxa were 
classified as occurring exclusively or mainly in water, while the majority (i.e. $\sim 25 \%$ of the total) are considered as able to live also in places that are not permanently submerged (Fig. 4c). These tolerant taxa accounted to an average RA of $\sim 47 \%$, while aerophilous diatoms such as D. perpusilla and P. marginulatum were found especially in permafrost-fed springs with low water discharge (e.g. MR-RG1, MR-RG2, MR-RG3 and AMRG3), where they showed RA between around 20 and $80 \%$ of the total diatom abundance. In general, the

Tab. 2. List of the 42 taxa used for the NMDS analysis (i.e. present with relative abundance $\geq 0.5 \%$ in at least two samples).

\begin{tabular}{|c|c|c|c|c|c|c|}
\hline Taxa & Code & $\mathbf{N r}$ & MRA & Sample & $\mathrm{pH}$ & TP \\
\hline Achnanthidium minutissimum var. minutissimum (Kützing) Czarnecki & ADMI & 18 & 78.14 & AM-REF-M & $\mathrm{cm}$ & id \\
\hline Diadesmis perpusilla (Grunow) D.G. Mann & DPER & 17 & 80.78 & AM-RG3-E & $\mathrm{cm}$ & o \\
\hline Diatoma mesodon (Ehrenberg) Kützing & DMES & 16 & 61.75 & AM-RG3-M & $\mathrm{cm}$ & $\mathrm{m}$ \\
\hline Psammothidium helveticum (Hustedt) Bukhtiyarova \& Round & PHEL & 14 & 76.01 & MR-REF2-E & al & $\mathrm{m}$ \\
\hline Psammothidium daonense (Lange-Bertalot) Lange-Bertalot & PDAO & 14 & 11.85 & MR-RG2-M & $\mathrm{cm}$ & o \\
\hline Psammothidium marginulatum (Grunow) Bukhtiyarova \& Round & PMRG & 13 & 87.93 & MR-RG3-E & ap & o \\
\hline Encyonema silesiacum (Bleisch) D.G. Mann & ESLE & 9 & 13.50 & AM-RG3-M & $\mathrm{cm}$ & id \\
\hline Encyonema minutum (Hilse) D.G. Mann & ENMI & 8 & 4.10 & SU-RG1-M & $\mathrm{cm}$ & n.a. \\
\hline Psammothidium subatomoides (Hustedt) Bukhtiyarova \& Round & PSAT & 7 & 17.36 & AM-RG1-E & ap & om \\
\hline Psammothidium bioretii (H. Germain) Bukhtiyarova \& Round & PBIO & 7 & 4.55 & AM-RG4-M & $\mathrm{cm}$ & $\mathrm{m}$ \\
\hline Nitzschia perminuta (Grunow) M. Peragallo & NIPM & 6 & 3.64 & AM-RG4-M & al & om \\
\hline Hannaea arcus (Ehrenberg) R.M. Patrick & HARC & 6 & 2.83 & MR-REF1-E & al & om \\
\hline Meridion circulare (Greville) Agardh & MCIR & 5 & 27.88 & SU-RG2-M & al & id \\
\hline Rossithidium petersenii (Hustedt) Round \& Bukhtiyarova & RPET & 5 & 15.48 & SU-RG1-M & $\mathrm{cm}$ & o \\
\hline Achnanthidium minutissimum var. jakii (Rab.) Lange-Bertalot \& Ruppel & ADJK & 5 & 7.93 & MR-REF1-M & $\mathrm{cm}$ & n.a. \\
\hline Amphora pediculus (Kützing) Grunow & APED & 4 & 43.51 & SU-RG2-E & al & e \\
\hline Eunotia exigua (Brébisson ex Kützing) Rabenhorst & EEXI & 4 & 35.85 & MR-REF2-M & ac & id \\
\hline Psammothidium helveticum var. minor (Flower \& Jones) Buczkó & PHMI & 4 & 10.61 & MR-REF2-M & al & $\mathrm{m}$ \\
\hline Fragilaria rumpens (Kützing) G.W.F. Carlson & FRUM & 4 & 3.64 & AM-REF-M & $\mathrm{cm}$ & om \\
\hline Fragilaria gracilis Østrup & FGRA & 4 & 3.37 & MR-REF1-M & $\mathrm{cm}$ & om \\
\hline Achnanthidium lineare W. Smith & ACLI & 3 & 38.74 & SU-RG2-E & $\mathrm{cm}$ & n.a. \\
\hline Reimeria sinuata (W. Gregory) Kociolek \& Stoermer & RSIN & 3 & 14.35 & SU-RG1-E & $\mathrm{cm}$ & $\mathrm{m}$ \\
\hline Amphora inariensis Krammer & AINA & 3 & 6.97 & SU-RG2-M & n.a. & o \\
\hline Gomphonema parvulum (Kützing) Kützing & GPAR & 3 & 6.01 & SU-RG2-M & $\mathrm{cm}$ & e \\
\hline Eunotia palatina Lange-Bertalot \& Krüger & EPLT & 3 & 3.54 & MR-REF2-M & n.a. & n.a. \\
\hline Denticula tenuis Kützing & DTEN & 3 & 2.04 & SU-RG1-M & al & $\mathrm{m}$ \\
\hline Psammothidium sacculum (J.R. Kartner) Bukhtiyarova & PSAC & 3 & 2.00 & AM-RG4-M & n.a. & n.a. \\
\hline Nitzschia alpina Hustedt & NZAL & 3 & 1.84 & AM-REF-E & n.a. & o \\
\hline Undetermined pennate & UNPE & 3 & 1.30 & SU-RG2-E & n.a. & n.a. \\
\hline Gomphonema pumilum var. rigidum Reichardt \& Lange-Bertalot & GPRI & 3 & 1.15 & AM-REF-E & n.a. & id \\
\hline Planothidium lanceolatum (Brébisson ex Kützing) Lange-Bertalot & PTLA & 2 & 58.68 & MR-RG4-E & al & $\mathrm{e}$ \\
\hline Luticola mutica (Kützing) D.G. Mann & LMUT & 2 & 4.56 & MR-RG2-M & $\mathrm{cm}$ & e \\
\hline Fragilaria vaucheriae (Kützing) J.B. Peterson & FVAU & 2 & 4.20 & MR-RG4-M & al & e \\
\hline Fragilariforma virescens (Ralfs) D.M. Williams \& Round & FVIR & 2 & 3.30 & MR-REF1-E & $\mathrm{cm}$ & om \\
\hline Eunotia intermedia (Krasske ex Hustedt) Nörpel \& Lange-Bertalot & EUIN & 2 & 3.07 & MR-REF1-E & ap & o \\
\hline Adlafia suchlandtii (Hustedt) Monnier \& Ector & ADLS & 2 & 3.03 & SU-RG2-E & n.a. & n.a. \\
\hline Adlafia minuscula (Grunow) Lange-Bertalot & ADMS & 2 & 2.96 & MR-RG2-M & al & o \\
\hline Staurosira venter (Ehrenberg) Cleve \& J.D.Möller & SSVE & 2 & 1.76 & AM-RG4-E & al & me \\
\hline Eunotia bigibba Kützing & EBIG & 2 & 1.21 & AM-RG1-M & ap & o \\
\hline Cyclotella comensis Grunow & CCMS & 2 & 0.97 & MR-RG2-E & $\mathrm{cm}$ & n.a. \\
\hline Stephanodiscus minutulus (Kützing) Cleve \& Möller & STMI & 2 & 0.75 & AM-RG3-M & $\mathrm{ab}$ & he \\
\hline Craticula molestiformis (Hustedt) Mayama & CMLF & 2 & 0.61 & SU-RG1-M & al & e \\
\hline
\end{tabular}

Code, taxon code according to Lecointe et al. (1993); Nr, number of sample where each taxon occurred with relative abundance $>0.5 \%$; MRA, maximum relative abundance reached by each taxon in the sample set; Sample, diatom sample code for each surveyed headwater (as in Tab. 1); E, epilithic; M, epiphytic; $\mathrm{pH}$ and TP, preference for each diatom taxon for water $\mathrm{pH}$ and total phosphorus level, respectively, according to the classification proposed by Van Dam et al. (1994); ac, acidobiontic; ap, acidophilous; cm, circumneutral; al, alkaliphilous; ab, alkalibiontic; o, oligotraphentic; om, oligo-mesotraphentic; m, mesotraphentic; me, meso-eutraphentic; e, eutraphentic; he, hypereutraphentic; id, indifferent to P level; n.a., no classification available. 
epiphytic samples showed a higher proportion of hydrophilic taxa (e.g. P. daonense, Meridion circulare (Greville) Agardh, Encyonema silesiacum (Bleisch) Mann, D. mesodon) compared to their epilithic counterparts (Fig. 4c, Tab. 2).

\section{Diatom diversity and environmental variables}

Due to the very low number of diatom valvae that could be found in the samples collected from the surveyed glacier-fed headwaters, only epilithic and epiphytic samples from permafrost-fed and rhithral headwaters $(\mathrm{N}=22)$ were considered for the NMDS ordination. A screen-plot analysis of the stress values of NMDS conducted with increasing number of dimensions indicated two dimensions (D1 and D2) as sufficient to represent the variability of diatom assemblages in this study. The two-dimensional NMDS explained $86.62 \%$ of the data variance with a stress value of 0.15 , while NMDS analyses including more dimensions provided only slight improvements of both parameters.

The distribution of the samples within the NMDS space shows a partial grouping according to the water origin (i.e. permafrost-fed or rhithral). The samples from the two major rhithral streams (AM-REF and MR-REF1) are located close to the axis origin, and are accompanied by several epilithic and epiphytic samples from permafrost-fed headwaters (Fig. 5a). Samples from the smaller rhithral stream (MR-REF2) and from other permafrost-fed headwaters are instead located far away from the axis origin in the NMDS space, in relation to their high relative abundance of almost exclusive diatom taxa. In fact, both samples from the rock glacier-fed spring SURG2 showed high RA of $A$. lineare and A. pediculus, the epilithic sample from AM-RG3 and the epiphytic samples from the permafrost-fed waters AM-RG1, AM-RG3 and MR-RG2 showed particularly high abundance of $D$. perpusilla and D. mesodon, respectively (Fig. 5b). The epilithic sample from the permafrost-fed MR-RG3 showed high proportion of $P$. marginulatum, while both samples from MR-REF2 were dominated by varieties of $P$. helveticum and Eunotia spp. (Fig. 5b and Tab. 2). In contrast, all the samples grouped close to the axis origin were characterised by high relative abundances of $A$. minutissimum sensu lato, and, secondly, by $P$. daonense, several Fragilariaceae, Nitzschia spp., and Gomphonema pumilum var. rigidum Reichardt \& Lange-Bertalot (Fig. $5 b)$. The epilithic and epiphytic samples of the two major rhithral waters are located close to each other in the NMDS space, while are far from each other for all the permafrostfed waters, with the sole exception represented by

Tab. 3. Species richness and $\alpha$-diversity of epilithic and epiphytic diatom assemblages found in the headwaters surveyed in the AM, $\mathrm{MR}$, and SU sub-catchments.

\begin{tabular}{|c|c|c|c|c|}
\hline Sample & Taxa & S.I. \pm SD & Even & Hetr \\
\hline SU-RG1-E & 16 & $2.47 \pm 0.08$ & 0.62 & 5.54 \\
\hline SU-RG1-M & 27 & $3.03 \pm 0.09$ & 0.64 & 8.18 \\
\hline SU-RG2-E & 14 & $2.03 \pm 0.08$ & 0.53 & 4.08 \\
\hline SU-RG2-M & 23 & $2.69 \pm 0.08$ & 0.60 & 6.47 \\
\hline MR-RG1-E & 9 & $1.31 \pm 0.06$ & 0.41 & 2.48 \\
\hline MR-RG2-E & 10 & $1.72 \pm 0.07$ & 0.52 & 3.29 \\
\hline MR-RG2-M & 17 & $2.93 \pm 0.08$ & 0.72 & 7.60 \\
\hline MR-RG3-E & 8 & $0.70 \pm 0.08$ & 0.23 & 1.62 \\
\hline MR-RG4-E & 14 & $1.64 \pm 0.08$ & 0.43 & 3.13 \\
\hline MR-RG4-M & 16 & $2.20 \pm 0.08$ & 0.55 & 4.58 \\
\hline MR-REF1-E & 33 & $2.92 \pm 0.12$ & 0.58 & 7.58 \\
\hline MR-REF1-M & 33 & $2.88 \pm 0.01$ & 0.57 & 7.37 \\
\hline MR-REF2-E & 8 & $1.33 \pm 0.09$ & 0.44 & 2.51 \\
\hline MR-REF2-M & 11 & $2.22 \pm 0.07$ & 0.64 & 4.64 \\
\hline AM-RG1-E & 8 & $1.23 \pm 0.08$ & 0.41 & 2.35 \\
\hline AM-RG1-M & 16 & $2.25 \pm 0.09$ & 0.56 & 4.77 \\
\hline AM-RG3-E & 9 & $1.18 \pm 0.09$ & 0.37 & 2.26 \\
\hline AM-RG3-M & 22 & $2.19 \pm 0.11$ & 0.49 & 4.55 \\
\hline AM-RG4-E & 33 & $2.91 \pm 0.11$ & 0.58 & 7.50 \\
\hline AM-RG4-M & 41 & $3.17 \pm 0.11$ & 0.59 & 8.98 \\
\hline AM-REF-E & 31 & $2.87 \pm 0.11$ & 0.58 & 7.33 \\
\hline AM-REF-M & 21 & $1.57 \pm 0.11$ & 0.36 & 2.96 \\
\hline
\end{tabular}

Sample codes as in Tab. 2. Taxa, total number of taxa identified in each sample; S.I., Shannon Index; Even, evenness calculated on Shannon Index; Hetr, Hill's heterogeneity. 
AM-RG4, and to a lesser extent by MR-RG4 (Fig. 5a). On the other hand, no sample grouping is evident according to their location in the different sub-catchments studied.

The vector fitting revealed highly significant correlations between periphytic diatom and the water variables associated to water acidity, i.e. $\mathrm{pH}$ and alkalinity (Tab. 4), and to concentrations of several trace metals. POM content of epilithic samples showed a nearly significant $(\mathrm{P}<0.06)$ relation. On the contrary, no significant relation emerged with the variables related to a) $100 \%$

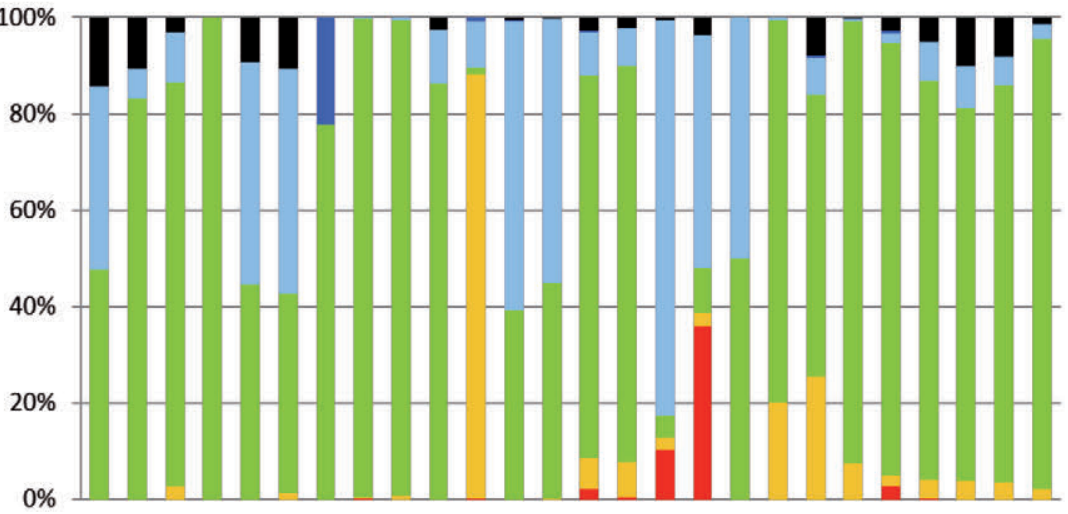

b) $100 \%$

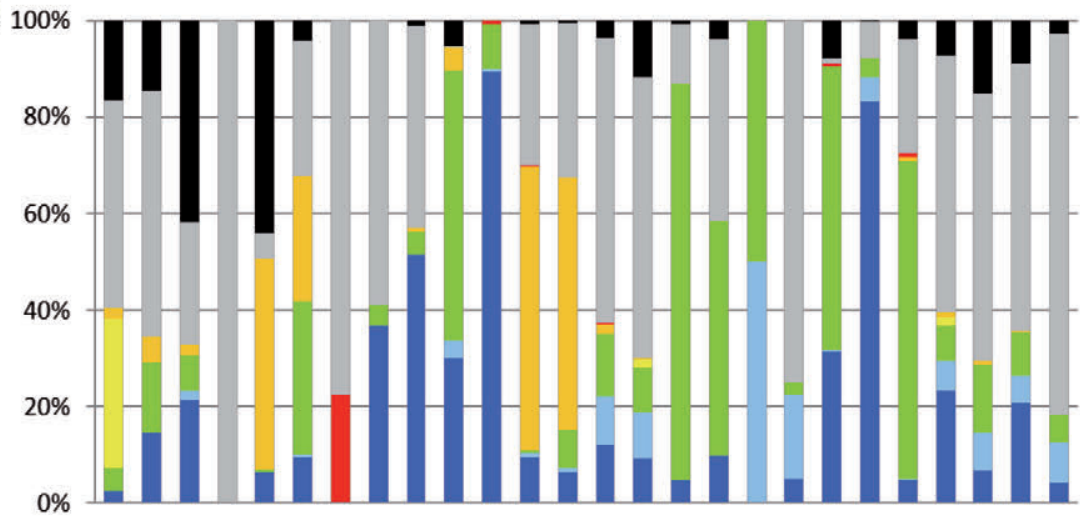

rest

m indifferent

alkalibiontic

alkaliphilus

circumneutral

acidophilus

acidobiontic

a rest

indifferent

aypereutraphentic

eutraphentic

meso-eutraphentic

mesotraphentic

oligo-mesotraphentic

घ oligotraphentic

n rest

nearly exclusively outside water

mainly on wet or temporary dry places

mainly in water, regularly on wet places

mainly in water

never outside water 1

ب ب ب ب ب ب ب ب

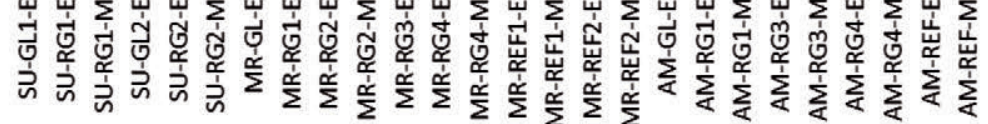

Fig. 4. Relative abundances of diatom taxa with different preferences for a) water $\mathrm{pH}, \mathrm{b}$ ) total phosphorus concentrations, c) moisture in the samples collected from the headwaters surveyed in the Italian Central Alps, according to the classification proposed by Van Dam et al. (1994). Sample codes as in Tab. 3. 

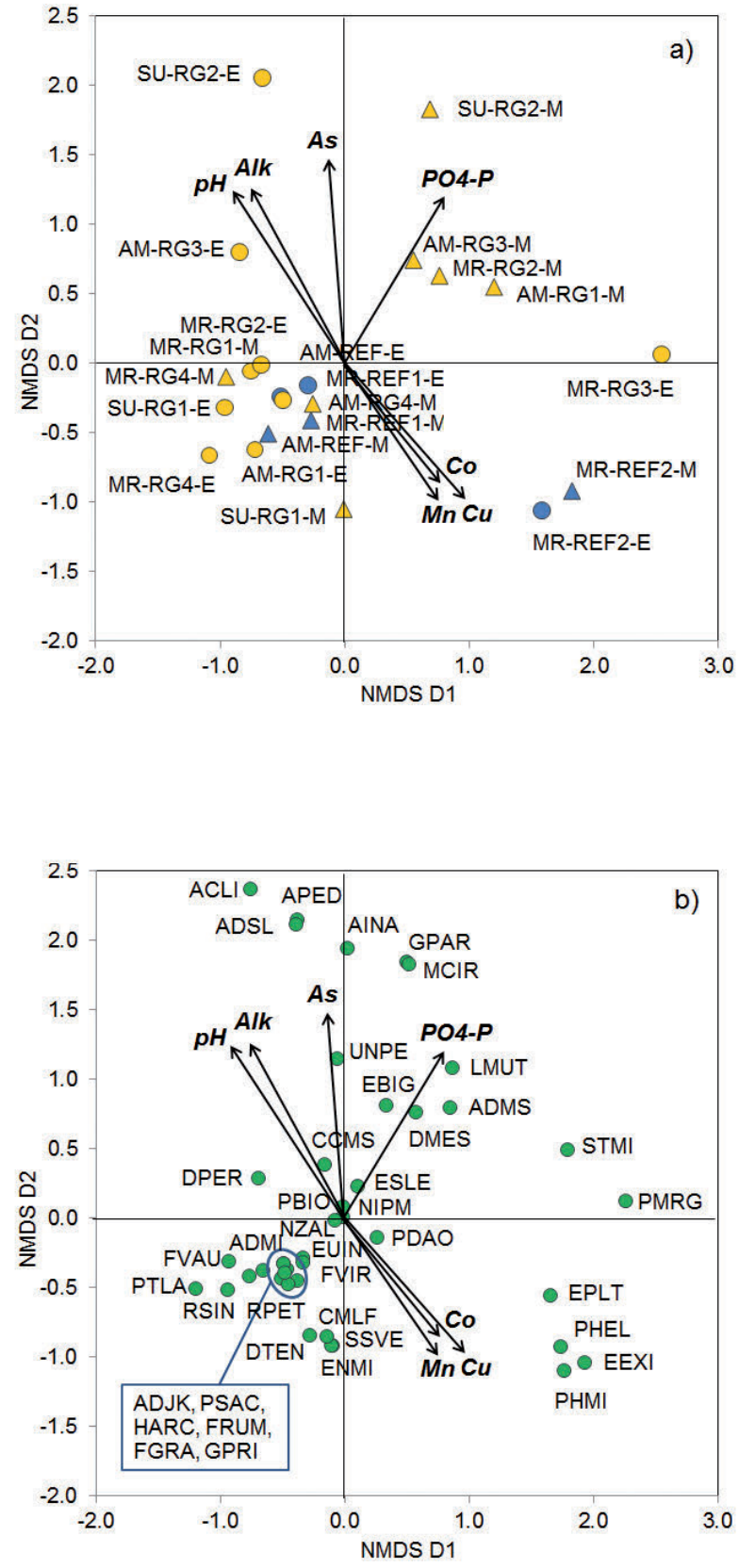

Fig. 5. NMDS ordination of a) the diatom samples collected from the surveyed headwaters based on relative abundance of epilithic and epiphytic diatom taxa reaching relative abundance $\geq 0.5 \%$ in at least two samples; b) species distributions in the ordination space. The vector fitting is restricted to environmental variables significantly correlated $(\mathrm{P} \leq 0.05)$ with the sample ordination. Vector orientation indicates the direction of the most rapid change for each variable, vectors lengths indicate the correlation between the variable and the sample ordination. Blue circles and triangles, epilithic and epiphytic samples, respectively, from rhithral headwaters fed by precipitation and/or groundwater; yellow circles and triangles, epilithic and epiphytic samples, respectively, from permafrost-fed headwaters. sample and species codes as in Tabs. 2 and 3. the water mineralization level, namely EC and major ions. The arrows of the acidity-associated variables point towards the positive side of NMDS dimension D2 (Fig. 5a), in agreement with the high $\mathrm{pH}$ and alkalinity of the headwater SU-RG2, while arrows associated to trace metals points to the negative region of NMDS D1, where samples characterized by lower $\mathrm{pH}$ and higher content of particulate organic matter in the epilithon are grouped. The location of the majority of the sample around the NMDS axis origin agrees with their intermediate chemical conditions (including nutrient level) independently from water type and sub-catchment (Fig. 5a).

Spearman rank correlation coefficients between sample scores on the NMDS dimensions and diatom-related variables (Tab. 3) confirmed the role of a few taxa (i.e. D.

Tab. 4. Significant $(P<0.05)$ correlation coefficients between sample scores on NMDS dimensions D1 and D2 and chemical and habitat variables (based on the $\mathrm{R}$ vector fitting function, $\mathrm{r}^{2}$ ), and diatom related variables (based on Spearman Rank correlation, $\rho)$.

\begin{tabular}{|c|c|c|c|}
\hline Variable & $\mathbf{C C}$ & $\mathbf{P}<$ & Dim \\
\hline $\mathrm{pH}$ & 0.51 & $* *$ & n.a. \\
\hline Alk & 0.47 & $* *$ & n.a. \\
\hline $\mathrm{HCO}_{3}$ & 0.46 & $* *$ & n.a. \\
\hline $\mathrm{PO}_{4}-\mathrm{P}$ & 0.44 & $*$ & n.a. \\
\hline $\mathrm{Cu}$ & 0.43 & $*$ & n.a. \\
\hline As & 0.46 & $* *$ & n.a. \\
\hline $\mathrm{Co}$ & 0.33 & $*$ & n.a. \\
\hline $\mathrm{Mn}$ & 0.37 & $*$ & n.a. \\
\hline $\mathrm{Zn}$ & 0.26 & 0.07 & n.a. \\
\hline POM & 0.23 & 0.08 & n.a. \\
\hline ADMI & -0.58 & $* *$ & D1 \\
\hline DPER & -0.53 & $* *$ & D1 \\
\hline DMES & 0.56 & $* *$ & D2 \\
\hline PDAO & 0.82 & $* * *$ & D1 \\
\hline PHEL & 0.61 & $* *$ & D1 \\
\hline EEXI & 0.45 & $*$ & D1 \\
\hline EPLT & 0.47 & $*$ & D1 \\
\hline $\mathrm{ac}$ & 0.62 & $*$ & D1 \\
\hline ap & 0.50 & $*$ & D1 \\
\hline \multirow[t]{2}{*}{ id } & -0.42 & $*$ & D1 \\
\hline & -0.45 & $*$ & D2 \\
\hline ow & 0.52 & $*$ & D2 \\
\hline \multirow[t]{2}{*}{$\mathrm{mw}$} & -0.67 & $* * *$ & D1 \\
\hline & -0.46 & $*$ & D2 \\
\hline ws & 0.87 & $* * *$ & D1 \\
\hline $\mathrm{ms}$ & -0.52 & $*$ & D1 \\
\hline
\end{tabular}

CC, correlation coefficient; Dim, NMDS dimension D1 or D2; n.a., not available. Diatom codes as in Tab. 2; diatom preferences for $\mathrm{pH}$, TP and moisture as in Tab. 2; ow, occurring almost exclusively in water; mw, occurring mainly in water; ws, mainly occurring in water but frequent also on wet substrata; ms, mainly occurring on wet or temporarily dry substrata; $* * * \mathrm{P}<0.001 ; * * \mathrm{P}<0.01 ; * \mathrm{P}<0.05$. 
perpusilla, D. mesodon, P. helveticum, E. exigua, Eunotia palatina Lange-Bertalot and Krüger) in determining the separation of several samples from permafrost-fed waters along both NMDS D1 and D2, from the most numerous group of samples, which were characterized by the dominance of common taxa, especially A. minutissimum var. minutissimum and $P$. daonense (both correlated to D1, Tab. 4). The correlation analyses revealed also a significant positive correlation between samples scores on D1 and the cumulative abundance of acidophilous and acidobiontic taxa, while taxa indifferent to the water phosphorus level showed a negative correlation with the same NMDS dimension (Tab. 3). Furthermore, samples score along NMDS D1 are correlated positively with the abundance of taxa occurring both in water and on moist soil, and negatively with taxa occurring mainly in water or on soil, respectively (Tab. 3). Sample scores on D2 are correlated positively to taxa occurring only in water and negatively to taxa occurring mainly in water, i.e. with scarce tolerance to desiccation (Tab. 3).

\section{DISCUSSION}

Research on alpine rock glaciers has recently gained attention as part of the mountain cryosphere that is increasingly threatened by the global climate warming (IPCC, 2013). However, the knowledge on the impact of climate change on permafrost thawing processes, and, consequently, on the chemical and biological quality of headwaters emerging from Alpine rock glaciers is still scarce (Colombo et al., 2018). Despite the limit posed by the small number of headwater surveyed, the present study confirms the results obtained by previous investigations on chemical features and biodiversity of permafrost-fed headwaters waters in the Central Alps (Thies et al., 2007, 2013, 2018; Ilyashuk et al., 2014; Lösch et al., 2015; Thaler et al., 2015), and provides new insight on aspects scarcely considered so far.

Similarly to what observed by the mentioned studies, the permafrost-fed springs and streams surveyed in each of the sub-catchments studied in this investigation showed higher EC values and elevated concentrations of $\mathrm{Ca}^{2+}$, $\mathrm{Mg}^{2+}$ and $\mathrm{SO}_{4}{ }^{2-}$ in comparison to rhithral headwaters with no contact with permafrost. The highest EC values detected in the present study $\left(\sim 500 \mu \mathrm{S} \mathrm{cm} \mathrm{cm}^{-1}\right)$ are comparable with those found in other catchments on crystalline bedrock of the Central Alps (Krainer et al., 2011; Thies et al., 2007, 2013; Lösch et al., 2015) and agree with the increasing observations that waters emerging from rock glaciers are characterized by higher solute concentrations (Colombo et al., 2018). On the opposite, the glacier-fed streams sampled in each subcatchment were characterized by low mineralization, as commonly observed in glacial waters of siliceous catchments worldwide (Slemmons et al., 2013). All headwaters surveyed in this study were very poor in soluble phosphorus, which likely represents a limiting factor for diatom growth, while concentrations of particulate TP and TN were particularly high in the glacier-fed streams, in agreement with previous studies of kryal waters (Hodson et al., 2004; Rott et al., 2006). The small number of studied sub-catchments does not allow understanding whether the higher TN concentrations detected in the southernmost headwaters may be due to $\mathrm{N}$ deposition, owing to their closeness to the atmospheric sources in the Po plain, or whether they are casual or related to geomorphological features. The organic content of epilithic biofilms appears to be independent from both water type and catchment geology, as it is likely related to local factors affecting the algal development, such as water turbidity and turbulence.

The studied permafrost-fed waters represent a quite heterogeneous group in comparison to glacier-fed and rhithral waters. In fact, all waters on the intrusive bedrock of the AM Valley were characterised by lower EC and ion concentrations than the waters on the metamorphic bedrock of the MR and SU catchments. This suggests that the chemical fingerprint of waters of different origin becomes less clear when considering catchments with different geology. Also the difference between permafrost-fed and rhithral waters is not as neat as observed in other areas of the Central Alps (Thies et al., 2007, 2013), which focused on geologically homogeneous watersheds, where chemical differences due to water origin are maximized. A strong geological control of type and amount of weathering products in headwaters has been outlined also in an extensive study on glaciated watershed in western USA (Fegel et al., 2016).

The double control exerted by water origin and watershed lithology over the concentrations of solutes in Alpine headwaters is evident also when considering trace metals. In fact, concentrations were very variable from site to site, but in general lower in the waters of AM catchment, and higher in permafrost-fed waters. This supports the hypothesis that trace metals of geological origin can become concentrated in rock glacier outlets due to a set of physical and chemical processes operating in permafrost, such as enrichment related to higher water residence time (Esposito et al., 2016) and different groundwater paths (MacLean et al., 1999; Frey and McClelland, 2009), freezing-thaw cycles (Williams et al., 2006; Thies et al., 2007, 2013), or acid rock drainage (ARD) induced by sulphide oxidation on freshly exposed rocks (Todd et al., 2012). In addition, the fact that only $\mathrm{Al}, \mathrm{Mn}$ and Fe reached higher levels in glacier-fed than in permafrost-fed waters in each catchment agrees with recent observations that the mentioned processes are not exclusive of permafrost, but can occur also in other high- 
altitude systems in relation to climate warming (Zaharescu et al., 2016). The present study did not provide further elements on the possible mechanism controlling trace metal enrichment in Alpine headwaters, as no relation was found with possible regulating factors, such as water $\mathrm{pH}$ or particulate matter. However, this study suggests that, although the measured concentrations of trace metals exceed the European guidelines for drinking waters only in a few cases, they potentially represent a threat at local level (e.g. for Alpine huts and cattle) in the predicted future context of reduced glacier mass and atmospheric precipitation.

The overall diversity of epilithic diatoms in the surveyed headwaters was somewhat lower with respect to previous studies (Thies et al., 2013; Lösch et al. 2015), in relation to the low species richness and pronounced dominance by a single or a few taxa in several permafrostfed water, especially in the MR sub-catchment. In general, the rhithral waters showed much higher $\alpha$-diversity, although the highest number of species and Shannon diversity was found in a water classified as permafrostfed (i.e. AM-RG4-E). The reason for the high diatom diversity of this sample is not clear, but the fact that this headwater emerges from a talus slope, which may contain no ice according to the probabilistic model for permafrost distribution in the Alps (Boeckli et al., 2012), might explain the similarity between the diatom composition of AM-RG4-E and AM-REF-E (see below). Glacier-fed waters surveyed in this study were characterized by extremely scarce diatom assemblages, in agreement with previous investigations in the Alps, Tatra and Himalaya (Uehlinger et al., 1998; Cantonati et al., 2001; Rott et al., 2006; Kawecka et al., 2012; Alber, personal communication), but partially in contrast with results from other mountain regions (Gesierich and Rott, 2012). In the glacier-fed headwaters surveyed in the present study diatom growth appears to be principally limited by physical constraints typically characterizing kryal waters, such as channel instability, reduction of light penetration and scorching exerted by the high mineral turbidity, which reset the diatom succession and reduce taxonomic richness (Bona et al. 2012; Fell et al., 2018).

When excluding the outliers represented by glacierfed waters, the differences between epilithic diatom communities in permafrost-fed and rhithral waters appears to be reduced in comparison with chemical differences. The multivariate analysis outlined that diatom assemblages of around one half of the permafrost-fed samples are highly comparable to those of their rhithral counterparts. These samples were characterized by intermediate chemical conditions, including a moderate to low trace metal concentrations, and their diatom assemblages were correspondingly dominated by the widespread reophilous and tolerant $A$. minutissmum var. minutissmum, which was accompanied by a set of subdominant species that are typical of oligotrophic, poorly mineralized, circumneutral to slightly acidic arcticalpine or high altitude freshwaters on crystalline bedrock, such as $D$. mesodon, D. perpusilla, $P$. daonense, and several fragilarioid and cymbelloid taxa (Cantonati et al., 2001; Rott et al., 2006; Rimet et al., 2007; Gesierich and Rott, 2004, 2012). Interestingly, diatom assemblages of the two rhithral streams sampled in the AM and MR subcatchments presented very similar diatom assemblages, despite the much higher mineralization level of the second stream. However, the two waters showed identical $\mathrm{pH}$, which is known as one of the key drivers for benthic diatoms in Alpine headwaters (Cantonati et al., 2001, 2012; Tolotti, 2001; Marchetto et al., 2009), and were characterized by similar habitat conditions (e.g. channel and surrounding vegetation, water turbidity and velocity). This stresses the need, when comparing the biodiversity of Alpine headwaters, of a holistic evaluation, that considers, beside water chemistry, also the habitat template and the temporal variability of physical constraints, as suggested by Uehlinger et al. (2010), Sertić Perić et al. (2015) and Feret et al. (2017).

The epilithic assemblages of the remaining permafrost-fed waters differed from those of rithral samples, mainly in relation to high abundances of single or a few taxa, that in turn appeared to be related to peculiar water characteristics. The samples with the most peculiar diatoms assemblage were separated from the group of "intermediate samples" according first to their $\mathrm{pH}$ and alkalinity, and secondly to the concentration of some trace metals. Alkaliphilous taxa (such as $A$. lineare) were dominant in SU-RG2-E, which showed also the highest concentration of $\mathrm{As}, \mathrm{Ba}$ and $\mathrm{Sr}$, while a set of acidophilous taxa (such as P. helveticum, and Eunotia spp.) were dominant at the other $\mathrm{pH}$ extreme, i.e. in samples that also showed the highest concentrations of $\mathrm{Co}, \mathrm{Cu}, \mathrm{Mn}$ and $\mathrm{Al}$. The sample MR-RG3-E represents an outlier, as, despite its slightly acidic $\mathrm{pH}$, it showed high concentration of several metals, especially $\mathrm{Ni}$, and was dominated by the acidobionthic P. marginulatum.

These results confirm previous evidences of the relation between diatom species composition of Alpine headwaters fed by thawing permafrost and heavy metal concentrations (Thies et al., 2013; Lösch et al., 2015), although trace metal concentrations in the surveyed waters were not so high as in other catchments studied in the Central Alps (Thies et al., 2007, 2013). Unlike in these previous studies, no univocal negative effect of trace metals on diatom diversity could be pointed out, since the reduced values of Shannon index and heterogeneity of the samples from permafrost-fed waters appeared to be independent from the trace metal levels. In addition, all the "separated" samples were collected in springs or 
streams with low water discharge and velocity, and showed, accordingly, high proportion of taxa that can tolerate periods of desiccation. This again stresses the importance of habitat features in regulating diatom biodiversity of Alpine headwaters (Rott et al., 2006).

Compared to previous investigations, the present study provides first information also on the epiphytic diatom assemblages of Alpine headwaters fed by permafrost, which, in general, were more diverse than epilithic assemblages in all water types. This higher diversity was not due to the presence of typically epiphytic taxa (such as M. circulare), but to the presence of higher proportion of rare taxa, such as several Encyonema, Gomphonema and Nitzschia species, and Denticula tenuis Kützing. In addition, the multivariate analysis revealed that epilithic and epiphytic diatom assemblages were very similar in rhithral streams, while they were quite different in all the permafrost-fed headwaters. The sole exception is represented by the AM-RG4 samples, which showed several characteristic similar to a rhithral water, as mentioned above, and to a lesser extent by MR-RG4. The difference between epilithic and epiphytic diatoms is not easy to be interpreted based on the chemical and habitat data collected in the present study. However, the aquatic mosses are likely able to provide a favourable physical habitat for diatom growth, and to smooth the effects of chemicals, such as trace metals. These aspects surely deserve to be investigated more in detail in the future.

\section{CONCLUSIONS}

The present study contributes to the chemical and biological characterisation of high mountain freshwaters in the Italian Alps, with a particular focus on waters fed by permafrost. The results support previous observations outlining the impact of thawing permafrost on the chemistry of headwaters emerging from active rock glaciers, in particular as regards solute content and trace metal concentrations. However, this study clearly indicates that the lithology of the watershed also plays a crucial role in determining the chemical features of headwaters on different bedrocks. In addition, the present study confirms the pivotal importance of $\mathrm{pH}$ in modulating the epilithic and epiphytic diatom assemblages of permafrost-fed waters, as well as the capacity of trace metals to negatively affect diatom diversity and to select tolerant diatom species in these waters. On the contrary, the other chemical variables seem to play a subordinate role, despite the high variability of electrical conductivity and major ion concentrations found in the surveyed waters.

The comparison of chemistry and diatom diversity in waters with different origin, i.e. fed by glacial melt water, permafrost thawing, and precipitation/groundwater, provides useful information to predict the possible future changes in the physical chemical and biological features of Alpine headwaters in relation to the progressing climate-related glacial retreat. In particular, differently to what predicted for other elements of the biota, especially macroinvertebrates (Khamis et al., 2014), the diatom $\alpha$ diversity of kryal headwaters does not seem to be threatened by the glacier retreat. On the contrary, kryal diatom assemblages are expected to become more diverse thanks to the improving environmental condition (i.e. lower physical and chemical shear stress). On the other side, permafrost-fed waters are characterized by a lower diatom $\alpha$-diversity of the biota, mainly in relation to their enrichment in trace metals, but possibly also to limiting physical habitat conditions, such as low discharge. This suggests that permafrost-fed waters might play a moderate role as biodiversity refugia (Hotaling et al., 2017) for benthic microalgae in a warmer future with reduced precipitations. On the contrary, a homogenization and banalization of the periphytic diatom assemblages at both headwater and regional level (i.e. loss of $\beta$ - and $\gamma$ diversity) can be predicted for the future, due to both the selection of a few tolerant taxa (Fell et al., 2018) and to the reduction of habitat variability. Within this context, the wide variability of Alpine headwaters in relation to water origin, watershed lithology and individual habitat features, seems to have a larger potential in preserving the high-altitude biodiversity. We advocate an increase in the number of case studies across habitats, seasonal aspects and biological groups, in order to improve the understanding the processes affecting diatom diversity in high altitude waters of different origin, and to provide more robust and generalized assessment of the ecological role of these aquatic habitats in the next decades.

\section{ACKONWLEDGEMENTS}

The research was financially supported by the Edmund Mach Foundation. The authors want to thank the technical staff of the Hydrochemistry Lab at FEM, and of the Water Chemistry lab at the CNR-IRSA. A special thank goes to Stefano Brighenti for his precious help during the field work.

\section{REFERENCES}

Adler S, 2015. [Das Klima von Tirol-Südtirol-Belluno: 19812010, Vergangenheit-Gegenwart-Zukunft].[Report in German]. Zentralanstalt für Meteorologie und Geodynamik, Südtirol Abteilung Brand- und Zivilschutz, Bozen: 102 pp.

APAT, CNR-IRSA, 2003. [Determinazione di elementi chimici mediante spettroscopia di emissione con sorgente al plasma (ICP-OES)]. In: [Metodi analitici per le acque].[Manual in German]. CNR-IRSA. 
APHA-AWWA-WPCF, 2017. Standard method for the Examination of Water and Wastewater, $23^{\text {rd }}$ ed. Am. Publ. Healts Ass., Washington.

Baroni C, Carton A, Seppi R, 2004. Distribution and behaviour of rock glaciers in the Adamello- Presanella Massif (Italian Alps). Permafr. Periglac. Process 15:243-259.

Beniston M, Farinotti D, Stoffel M, Andreassen LM, Coppola E, Eckert N, Fantini A, Giacona F, Hauck C, Huss M, Huwald H, Lehning M, López-Moreno JI, Magnusson J, Marty C, Morán-Tejéda E, Morin S, Naaim M, Provenzale A, Rabatel A, Six D, Stötter J, Strasser U, Terzago S, Vincent C, 2018. The European mountain cryosphere: a review of its current state, trends, and future challenges. Cryosphere 12:759-794.

Boeckli L, Brenning A, Gruber S, Noetzli J, 2012. Permafrost distribution in the European Alps: calculation and evaluation of an index map and summary statistics. Cryosphere 6:807-820.

Bona F, La Morgia V, Falasco E, 2012. Predicting river diatom removal after shear stress induced by ice melting. River Res. Appl. 28:1289-1298.

Brown LE, Khamis K, Wilkes M, Blaen P, Brittain JE, Carrivick JL, Fell S, Friberg N, Füreder L, Gislason GM, Hainie S, Hannah DM, James WHM, Lencioni V, Olafsson JS, Robinson CT, Saltveit SJ, Thompson C, Milner AM, 2018. Functional diversity and community assembly of river invertebrates show globally consistent responses to decreasing glacier cover. Nat. Ecol. Evol. 2:325-333.

Callegari E, Brack P, 2002.Geological map of the Tertiary Adamello batholith (northern Italy): Explanatory notes and legend. Mem. Sci. Geol. 54:19-49.

Cantonati M, Corradini G, Juttner I, Cox EJ, 2001. Diatom assemblages in high mountain streams of the Alps and the Himalaya. Nova Hedwigia 123:37-61.

Cantonati M, Angeli N, Bertuzzi E, Spitale D, Lange-Bertalot H, 2012. Diatoms in springs of the Alps: spring types, environmental determinants, and substratum. Freshw. Sci. 31:499-524.

Carturan L, Zuecco G, Seppi R, Zanoner T, Borga M, Carton A, Dalla Fontana G, 2016. Catchment-scale permafrost mapping using spring water characteristics. Permafr. Periglac. Process. 27:253-270.

Colombo N, Gruber S, Martin M, Malandrino M, Magnani A, Godone D, Freppaz M, Fratianni S, Salerno F, 2018a. Rainfall as primary driver of discharge and solute export from rock glaciers: The Col d'Olen Rock Glacier in the NW Italian Alps. Sci. Total Environ. 639:316-330.

Colombo N, Salerno F, Gruber S, Freppaz M, Williams M, Fratianni S, Giardino M, 2018b. Review: Impacts of permafrost degradation on inorganic chemistry of surface fresh water. Glob. Planet. Change 162:69-83.

Council of the European Union, 1998. Directive on the quality of water intended for human consumption, 98/83/CE. Official Journal 330:32-54.

Dobinski W, 2011. Permafrost. Earth. Sci. Rev. 108:158-169.

Engel M, Brighenti S, Bruno MC, Tolotti M, Comiti F, 2018. Multi-proxy approach for characterizing rock glacier outflows, p.1020-1021. In: P. Deline, X. Bodin and L. Ravanel (eds.), Proceedings of the $5^{\text {th }}$ European Conference on Permafrost, Chamonix, France.
Esposito A, Engel M, Ciccazzo S, Daprà L, Penna D, Comiti, Zerbe S, Brusetti L, 2016. Spatial and temporal variability of bacterial communities in high alpine water spring sediments. Res. Microbiol. 167:325-333.

European Committee for Standardization, 2004. European Standard 14407. Water quality- guidance standard for the identification, enumeration and interpretation of benthic diatom samples from running waters. CEN, Brussels.

European Committee for Standardization, 2014. European Standard 13946. Water quality - Guidance for the routine sampling and preparation of benthic diatoms from rivers and lakes.. CEN, Brussels.

European Environment Agency, 2009. Regional climate change and adaptation: the Alps facing the challenge of changing water resources. EEA, Copenahgen: $143 \mathrm{pp}$.

Fegel TS, Baron JS, Fountain AG, Johnson GF, Hall EK, 2016. The differing biogeochemical and microbial signatures of glaciers and rock glaciers. J. Geophys. Res. Biogeosci. 121:919-932.

Fell SC, Carrivick JL, Brown LE, 2017. The multitrophic effects of climate change and glacier retreat in mountain rivers. BioScience 67:897-911.

Fell SC, Carrivick JL, Kelly MG, Füreder L, Brown LE, 2018. Declining glacier cover threatens the biodiversity of alpine river diatom assemblages. Glob Change Biol. 24:5828-5840.

Feret L, Bouchez A, Rimet F, 2017. Benthic diatom communities in high altitude lakes: a large scale study in the French Alps. Ann. Limnol.-Int. J. Lim. 53:411-423.

Frey KE, McClelland JW, 2009. Impacts of permafrost degradation on arctic river biogeochemistry. Hydrol. Process. 23:169-182.

Gesierich D, Rott E, 2004. Benthic algae and mosses from aquatic habitats in the catchment of a glacial stream (Rotmoos, Ötztal, Austria). Ber. Naturwiss.-med. Ver. Innsb. 91:7-42.

Gesierich D, Rott E, 2012. Is diatom richness responding to catchment glaciation? A case study from Canedian headwater streams. J. Limnol. 71:e7.

Gobiet A, Kotlarski S, Beniston M, Heinrich G, Rajczak J, Stoffe M, 2014. $21^{\text {st }}$ century climate change in the European Alps - A review. Sci. Total Environ. 493:1138-1151.

Haeberli W, Schaub Y, Huggel C, 2017. Increasing risks related to landslides from degrading permafrost into new lake in deglaciating mountain ranges. Geomorphology 293:405-417.

Harris SA, Pedersen DE, 1998. Thermal regimes beneath coarse blocky materials. Permafr. Periglac. Process. 9:107-120.

Harris C, Arenson LU, Christiansen HH, Etzelmüller B, Frauenfelder R, Humlum O, Kääb A, Gruber S, Haeberli W, Hölzle M, Nötzli J, Hauck C, Isaksen K, Lehning M, Phillips M, Matsuoka N, Murton JB, Ross N, Seppälä M, Springman SM, Vonder Mühll D, 2009. Permafrost and climate in Europe: monitoring and modelling thermal, geomorphological and geotechnical responses. Earth Sci. Rev. 92:117-171.

Hauer FR, Lamberti GA, 2011. Methods in stream ecology. Academic Press, London: 896 pp.

Hill MO, 1973. Diverisity and evenness: a unifying notation and its consequences. Ecology 54:577-586.

Hodson A, Mumford P, Lister D, 2004. Suspended sediment and phosphorous in proglacial rivers: Bioavailability and 
potential impacts upon the P status of ice-marginal receiving waters. Hydrol. Process. 18:2409-2422.

Holm S, 1979. A simple sequentially rejective multiple test procedure. Scan. J. Stat. 6:65-70.

Hotaling S, Finn DS, Giersch JJ, Weisrock DW, Jacobsen D, 2017. Climate change and alpine stream biology: progress, challenges, and opportunities for the future. Biol. Rev. 92:2024-2045.

Hlúbikova D, Blanco S, Falasco E, Gomà J. Hoffmann L., Ector L, 2009. Nitzschia alicae sp. nov. and N. puriformis sp. nov., new diatoms from European rivers and comparison with the type material of $N$. sublinearis and N. pura. J. Phycol. 45:742-760.

Ilyashuk BP, Ilyashuk EA, Psenner R, Tessadri R, Koinig KA, 2014. Rock glacier outflows may adversely affect lakes: lessons from the past and present of two neighboring water bodies in a crystalline-rock watershed. Environ. Sci. Technol. 48:6192-6200.

IPCC, 2013. Climate change 2013. In: T.F. Stocker, D. Qin, G.K. Plattner, M. Tignor, S.K. Allen, J. Boschung, A. Nauels, Y. Xia, V. Bex and P.M. Midgley (eds.). The physical science basis. Contribution of Working Group I to the Fifth Assessment Report of the Intergovernmental Panel on Climate Change. Cambridge University Press, Cambridge: $1552 \mathrm{pp}$.

Jansson P, Hock R, Schneider T, 2003. The concept of glacier storage: A review. J. Hydrol. 282:116-129.

Jones DB, Harrison S, Anderson K, Betts RA, 2018. Mountain rock glaciers contain globally significant water stores. Sci. Rep. 8:2834.

Kawecka B, 2012. Diatom diversity in streams of the Tatra National Park (Poland) as indicators of environmental conditions. In: A. Witkowski (ed.), Diatom monographs. Gantner Verlag, Ruggell: 213 pp.

Khamis KD, Hannah M, Brown LE, Tiberti R, Milner AM, 2014. The use of invertebrates as indicators of environmental change in alpine rivers and lakes. Sci. Total Environ. 493:1242-1254.

Krainer K, Mostler W, Spotl C, 2007. Discharge from active rock glaciers, Austrian Alps: a stable isotopeapproach. Aust. J. Earth Sci. 100:102-112.

Krainer K, Chinellato G, Tonidandel D, Lang K, 2011. Analysis of the contribution of permafrost ice to the hydrological water regime. WP7 Water resources. Report action 7.3, PermaNET project. Available from: http://www.permanetalpinespace.eu/archive/pdf/WP7_3.pdf

Krammer K, 2000. The genus Pinnularia. In: H. Lange-Bertalot (ed.), Diatoms of the European inland water and comparable habitats., Gantner Verlag, Ruggell, Germany, 1: 703 pp.

Krammer K, Lange-Bertalot H, 1986-2004. Süßwasserflora von Mitteleuropa. In: H. Ettl, J. Gerloff, H. Heynig, D. Mollenhauer (eds.), Gustav Fischer Verlag, Stuttgart, Germany, Bacillariophyceae, Naviculaceae, 2/1: 876 pp.; Bacillariaceae, Epithemiaceae, Surirellaceae, 2/2: 596 pp.; Centrales, Fragilariaceae, Eunotiaceae, 2/3: 576 pp.; Achnanthaceae, 2/4: 468 pp.

Kruskal JB, Wish M, 1978. Multidimensional scaling. Sage Publications, Beverly Hills: 93 pp.

Lange-Bertalot H, 2001. Navicula sensu stricto, 10 genera separated from Navicula sensu stricto, Frustulia. In: H.
Lange-Bertalot (ed.), Diatoms of the European inland water and comparable habitats. Gantner Verlag, Ruggell: 526 pp.

Lange-Bertalot H, Hofmann G, Werum M, Cantonati M, 2017. Freshwater benthic diatoms of Central Europe: Over 800 common species used in ecological assessment. In: M. Cantonati, M.G. Kelly and H. Lange-Bertalot (eds.), Koeltz Botanical Books. Oberreifenberg: 942 pp.

Lange-Bertalot H, Malgorzata B, Witkowski A, Tagliaventi N, 2011. Eunotia and some related genera. In: H. LangeBertalot (ed.), Diatoms of the European inland water and comparable habitats. Gantner Verlag, Ruggell.

Lecointe C, Coste M, Prygiel J, 1993. "Omnidia": software for taxonomy, calculation of diatom indices and inventories management. Hydrobiologia 269:509.

Legendre P, Legendre L, 1998. Numerical ecology. Elsevier, Amsterdam: 300 pp.

Lösch B, Tolotti M, Alber R, 2015. [Quellen und Bäche mit Blockgletschereinfluss].[Article in German]. Geo. Alp. 12:163-182.

MacLean R, Oswood MW, Irons JG, McDowell WH, 1999. The effect of permafrost on stream biogeochemistry: a case study of two streams in the Alaskan (USA) taiga. Biogeochemistry 47:239-267.

Marchetto A, Rogora M, Boggero A, Musazzi S, Lami A, Lotter AF, Tolotti M, Thies H, Psenner R, Massaferro J, Barbieri A, 2009. Response of Alpine lakes to major environmental gradients, as detected through planktonic, benthic and sedimentary assemblages. Fundam. Appl. Limnol. Special Issues Adv. Limnol. 62:419-440.

Marchetto A, Arisci S, Tartari GA, Balestrini R, Tait D, 2014. [Stato ed evoluzione temporale della composizione chimica delle deposizioni atmosferiche nelle aree forestali della rete CONECOFOR].[Article in Italian]. Forest@11:72-85.

Milner AM, Khamis K, Battin TJ, Brittain JE, Barrand NE, Füreder L, Cauvy-Fraunié S, Gíslason GM, Jacobsen D, Hannah DM, Hodson AJ, Hood E, Lencioni V, Ólafsson JS, Robinson CT, Tranter M, Brown LE, 2017. Glacier shrinkage driving global changes in downstream systems. PNAS 114:9770-9778.

Montrasio A, Berra F, Cariboni M, Ceriani M, Deichmann N, Ferliga C, Gregnanin A, Guerra S, Guglielmin M, Jadoul F, Longhin M, Mair V, Mazzoccola D, Sciesa E, Zappone A, 2012. [Note illustrative della Carta Geologica d'Italia alla scala 1:50.000, Foglio 024]. [in Italian]. ISPRA, Servizio Geologico d'Italia, Bormio: $150 \mathrm{pp}$.

Oksanen J, Blanchet FG, Kindt R, Legendre P, Minchin PR, O'Hara R, Simpson GL, Solymos P, Stevens MHH, Wagner H, 2015. Package 'vegan'. Community ecology package, ver.2.2-1.

Pielou EC, 1975. Ecological diversity. J. Eiley \& Sons, New York: $165 \mathrm{pp}$.

Potapova MG, Hamilton PB, 2007. Morphological and ecological variation within the Achnanthidium minutissimum (Bacillariophyceae) species complex. J. Phycol. 43:561-575.

$\mathrm{R}$ Core Team (2015). A language and environment for statistical computing. R Foundation for Statistical Computing, Vienna, Austria. http://www.R-project.org/

Rimet F, Gomà J, Cambra J, Bertuzzi E, Cantonati M, Cappelletti C, Ciutti F, Cordonier A, Coste M, Delmas F, Tison J, Tudesque L, Vidal H, Ector L, 2007. Benthic 
diatoms in western european streams with altitudes above $800 \mathrm{~m}$ : characterisation of the main assemblages and correspondence with ecoregions. Diatom Res. 22:147-188.

Rogora M, Mosello R, Arisci S, Brizzio MC, Barbieri A, Balestrini R., Waldner P, Schmitt M, Stähli M, Thimonier A, Kalina M, Puxbaum H, Nickus U, Ulrich, Probst A, 2006. An overview of atmospheric deposition chemistry over the Alps: present status and long-term trends. Hydrobiologia 562:17-40.

Rott E, Cantonati M, Füreder L, Pfister P, 2006. Benthic algae in high altitude streams of the Alps - a neglected component of the aquatic biota. Hydrobiologia 562:195-216.

Schoeneich P, Dall'Amico M, Deline P, Zischg A, 2011. Hazards related to permafrost and to permafrost degradation. Stateof-the-art report 6.2, PermaNET project.

Seppi R, Carton A, Zumiani M, Dall'Amico M, Zampedri G, Rigon R, 2012. Inventory, distributiom amd topographiv features of rock glaciers in the southern region of the eastern Italian Alps (Trentino). Geogr. Fis. Dinam. Quat. 35:185197.

Sertić Perić M, Jolidon C, Uehlinger U, Robinson CT, 2015. Long-term ecological patterns of alpine streams: an imprint of glacial legacies. Limnol. Oceanogr. 60:992-1007.

Shannon CE, Weaver W, 1949. The mathematical theory of comunication. Univerity of Illinois Press, Urbana: $132 \mathrm{pp}$.

Slemmons KH, Saros JE, Simon K, 2013. The influence of glacial meltewater on alpin acquatic ecosystems: a review. Environ. Sci. Process Impact. 15:1794-1806.

Thaler B, Tait D, Tolotti M, 2015. [Permafrost und seine Auswirkungen auf die Ökologie von Hochgebirgsseen]. [Article in German]. Geo. Alp 12:183-234.

Thies H, Nickus U, Mair V, Tessadri R, Tait D, Thaler B, Psenner $\mathrm{R}, 2007$. Unexpected response of high alpine lake water to climate warming. Environ. Sci. Technol. 41:7424-7429.

Thies H, Nickus U, Tolotti M, Tessadri R, Krainer K, 2013. Evidence of rock glacier melt impacts on water chemistry and diatoms in high mountain streams. Cold Reg. Sci. Technol. 96:77-85.
Thies H, Nickus U, Tessadri R, Tropper P, Krainer K, 2018. Peculiar arsenic, copper, nickel, uranium, and yttrium-rich stone coatings in a high mountain stream in the Austrian Alps. Austrian J. Earth Sc. 110. Doi: 10.17738/ ajes.2017.0012.

Todd AS, Manning AH, Verplanck PL, Crouch C, McKnight DM, Dunham R, 2012. Climate-change-driven deterioration of water quality in a mineralized watershed. Environ. Sci. Technol. 46:9324-9332.

Tolotti M, 2001. Phytoplankton and littoral epilithic diatoms in high mountain lakes of the Adamello-Brenta Regional Park (Trentino, Italy) and their relationship to trophic status and acidification risk. J. Limnol. 60:171-188. Doi: 10.4081 /jlimnol.2001.1.171.

Uehlinger U, Zah R, Bürgi H, 1998. The Val Roseg project: temporal and spatial patterns of benthic algae in an Alpine stream ecosystem influenced by glacier runoff. Hydrology, water resources and ecology in headwaters. Proceedings of the HeadWater ' 98 Conference, Merano, Italy. IAHS Publ. 248:419-424.

Uehlinger U, Robinson CT, Hieber M, Zah R, 2010. The physico-chemical habitat template for periphyton in alpine glacial streams under a changing climate. Hydrobiologia 657:107-121.

Van Dam H, Mertens A, Sinkeldam J, 1994. A coded checklist and ecological indicator values of freschwater diatoms from the Netherlands. Neth. J. Aquat. Ecol. 28:17-133.

Williams MW, Knauf M, Caine N, Liu F, Verplanck PL, 2006. Geochemistry and source waters of rock glacier outflow, Colorado Front Range. Permafr. Periglac. Process. 17: 13-33.

Zaharescu DG, Hooda PS, Burghelea CI, Polyakov V, PalancaSoler A, 2016. Climate change enhances the mobilization of naturally occurring metals in high altitude environments. Sci. Total Environ. 560-561:73-81.

Zemp MH, Haeberli W, Hoelzle M, Paul F, 2006. Alpine glaciers to disappear within decades? Geophys. Res. Lett. 33:1-4. 